\title{
CD73 Is Critical for the Resolution of Murine Colonic Inflammation
}

\author{
Margaret S. Bynoe, ${ }^{1}$ Adam T. Waickman, ${ }^{1}$ Deeqa A. Mahamed, ${ }^{1}$ \\ Cynthia Mueller, ${ }^{1}$ Jeffrey H. Mills, ${ }^{1}$ and Agnieszka Czopik ${ }^{2}$ \\ ${ }^{1}$ Department of Microbiology and Immunology, College of Veterinary Medicine, Cornell University, C5 149 VMC, \\ Ithaca, NY 14853, USA \\ ${ }^{2}$ Department of Biology, Massachusetts Institute of Technology, Cambridge, MA 02139, USA
}

Correspondence should be addressed to Margaret S. Bynoe, msb76@cornell.edu

Received 14 May 2012; Revised 7 July 2012; Accepted 11 July 2012

Academic Editor: Linda F. Thompson

Copyright (C) 2012 Margaret S. Bynoe et al. This is an open access article distributed under the Creative Commons Attribution License, which permits unrestricted use, distribution, and reproduction in any medium, provided the original work is properly cited.

\begin{abstract}
CD73 is a glycosyl-phosphatidylinositol-(GPI-) linked membrane protein that catalyzes the extracellular dephosphorylation of adenosine monophosphate (AMP) to adenosine. Adenosine is a negative regulator of inflammation and prevents excessive cellular damage. We investigated the role of extracellular adenosine in the intestinal mucosa during the development of Dextran-SulfateSodium-(DSS-)salt-induced colitis in mice that lack CD73 $\left(\mathrm{CD}^{-/-}\right)$and are unable to synthesize extracellular adenosine. We have found that, compared to wild-type (WT) mice, $\mathrm{CD}_{3}{ }^{-/-}$mice are highly susceptible to DSS-induced colitis. CD73 ${ }^{-/-}$mice exhibit pronounced weight loss, slower weight recovery, an increase in gut permeability, a decrease in expression of tight junctional adhesion molecules, as well as unresolved inflammation following the removal of DSS. Moreover, colonic epithelia in CD73 ${ }^{-/-}$ mice exhibited increased TLR9 expression, high levels of IL- $1 \beta$ and TNF- $\alpha$, and constitutive activation of NF- $\kappa$ B. We conclude that $\mathrm{CD} 73$ expression in the colon is critical for regulating the magnitude and the resolution of colonic immune responses.
\end{abstract}

\section{Introduction}

Many mechanisms are proposed to lead to chronic inflammation of the gut mucosa, which is exemplified by Crohn's disease (CD) and ulcerative colitis (UC), also known as inflammatory bowel diseases (IBDs) [1]. These include dysregulation of the innate immune response to enteric flora $[2,3]$, increased epithelial barrier permeability [4], and defective regulation of the adaptive immune response [5]. Several susceptibility genes carrying mutations have been found in patients suffering from IBD [1]. Mutations in the human leukocyte antigen genes are associated with both $\mathrm{CD}$ and UC [6], while mutations in the Nuclear Oligomerization Domain (NOD) $1 / 2$ genes are associated with CD $[1,7]$.

The passage of soluble molecules across the epithelial barrier of the gastrointestinal tract is a tightly regulated process [8]. Nutrients must be absorbed into the bloodstream, while commensal bacteria normally found in the GI tract, and their associated antigens, must be kept isolated from intraepithelial lymphocytes to avoid abnormal and persistent immune responses that can cause inflammation or other types of trauma $[8,9]$. The purine nucleoside adenosine, its receptors and ectoenzymes (CD39 and CD73) are emerging as critical players in the regulation of intestinal immunemediated inflammation [10-12].

During inflammation and the initiation of primary immune responses, adenosine triphosphate (ATP) is released into the extracellular environment following cell damage [13]. Extracellular ATP, a damage-associated molecule and a potent activator of the immune response, increases the production of proinflammatory cytokines such as IL- $1 \beta$, IL6 , TNF- $\alpha$, and IL-12. ATP also enhances the potency of the oxidative stress response of activated macrophages [13]. The immune system has various mechanisms to resolve these inflammatory signals. One such mechanism is activated by the extracellular adenosine generated through the activities 
of CD39 and CD73 [14]. CD39 catabolizes extracellular ATP to adenosine monophosphate (AMP) while CD73 (a $5^{\prime}$ ectonucleotidase) further converts AMP to adenosine [15]. Adenosine inhibits production of TNF- $\alpha$, IL- $1 \beta$, IL- 6 , IL12 , and IL-23 by monocytes and dendritic cells (DCs) and promotes the production of IL-10 [16]. Therefore, CD73generated adenosine acts as a negative feedback signal to prevent uncontrolled inflammation that would otherwise cause collateral damage to healthy tissues.

CD39, CD73, and adenosine receptors are expressed on intestinal epithelial cells and various immune cell types [1719]. CD39 and CD73 have recently been shown to be important for $\mathrm{T}$ regulatory cell function [20], and mice lacking these enzymes exhibit very severe IBD in trinitrobenzene sulfonate (TNBS) colitis model $[10,11]$. Adenosine mediates its effects through four $G$ protein-coupled receptors: $A_{1} A R ; A_{2 A} A R ; A_{2 B} A R ; A_{3} A R$ [14]. Adenosine receptors are expressed in the intestine of mice and humans, and signaling through these receptors is critical for regulation of the severity of intestinal inflammation following a wide range of insults [16]. For example, activation of the $\mathrm{A}_{2 \mathrm{~A}}$ receptor has been shown to reduce intestinal inflammation in mice by decreasing leukocyte infiltration and inhibiting proinflammatory cytokines [21], while inhibition of adenosine kinase improves IBD pathology in DSS-induced colitis [22].

Because of the anti-inflammatory role of adenosine and its association with IBD, we investigated the role of extracellular (CD73-generated) adenosine in DSS-induced colitis in mice deficient in CD73. CD73 ${ }^{-/-}$mice developed markedly more severe colitis and exhibit unresolved inflammation and produce high levels of the proinflammatory cytokines IL- $1 \beta$ and TNF- $\alpha$ compared to WT mice. Colonic epithelial cells from $\mathrm{CD} 73^{-/-}$mice show increased TLR-9 and NF- $\kappa$ B activity and have decreased expression of several tight-junctionassociated proteins when compared to WT mice, along with an associated increase in gastrointestinal permeability. From these findings, we hypothesize that CD73-generated adenosine is a key modulator in gut inflammation and IBD and mediates its effects through regulating inflammation and maintaining epithelial barrier integrity.

\section{Materials and Methods}

2.1. Mice. C57BL/6 WT and $\mathrm{rag}^{-/-}$mice were purchased from Jackson Laboratories. CD73 ${ }^{-/-}$mice were obtained from Dr. Linda Thompson at the Oklahoma Medical Research Foundation [23]. Mice were bred and housed under specific pathogen-free conditions in the mouse facility at Cornell University. All procedures performed on mice were approved by the Cornell University IACUC. All mice used in these experiments were between 8 and 10 weeks old.

2.2. DSS-Induced Experimental Colitis. 3\% Dextran Sodium Sulfate (DSS, MW $=36,000-50,000$ ) was administered in drinking water to experimental animals [24]. Age-matched males and females WT and $\mathrm{CD} 73^{-/}$were used in these experiments. Weight loss was normally observed 4-5 days after the initiation of DSS treatment, and experiments were halted after animals lost $\sim 20 \%$ of initial body weight.
2.3. Passively Induced IBD. $\mathrm{CD}^{+}$cells were isolated from processed spleens and lymph nodes of naïve WT and $\mathrm{CD}^{-1-}$ mice by negative selection using magnetic beads (Invitrogen). $\mathrm{CD}^{+}$cells were further subdivided into $\mathrm{CD}^{+} \mathrm{CD} 45 \mathrm{RB}^{\text {high }} \mathrm{CD} 25^{-}$and $\mathrm{CD} 4{ }^{+} \mathrm{CD} 45 \mathrm{RB}^{\text {low }} \mathrm{CD} 25^{+}$populations using a BD-Biosciences FACS Aria system. Two million $\mathrm{CD} 4^{+} \mathrm{CD} 45 \mathrm{RB}^{\text {high }}$ cells from either WT or $\mathrm{CD} 73^{-/-}$ mice were injected into $\mathrm{rag}^{-/-}$mice. Some mice additionally received $2 \times 10^{6} \mathrm{CD} 4^{+} \mathrm{CD} 45 \mathrm{RB}^{\text {low }} \mathrm{CD} 25^{+}$cells isolated from either WT or $\mathrm{CD}^{2} 3^{-1-}$ mice. Mice were weighed daily for 45 days to track disease progression.

2.4. Isolation of Primary Colonic Epithelial Cells. Whole colons were isolated, the lumen exposed by a longitudinal cut, washed with $\mathrm{Ca}^{++} \mathrm{Mg}^{++}$free HBSS $+2 \% \mathrm{FBS}$, cut into 1-2 $\mathrm{mm}^{2}$ sections, and washed $2 \mathrm{X}$ with $\mathrm{Ca}^{++} \mathrm{Mg}^{++}$free HBSS $+2 \%$ FBS. The tissue was then incubated for $30 \mathrm{~min}$ at $37^{\circ} \mathrm{C}$ in $\mathrm{Ca}^{++} \mathrm{Mg}^{++}$free HBSS $+10 \%$ FBS $+1 \mathrm{mM}$ EDTA + $1 \mathrm{mM}$ DTT + penicillin/streptomycin. The digest was filtered through a $70 \mu \mathrm{m}$ mesh and spun at $200 \times \mathrm{g}$ for $10 \mathrm{~min}$. Primary colonic epithelial cells include resident intraepithelial lymphocytes (iELs), as no Percoll gradient was used to separate this population.

2.5. Flow Cytometry. Cells were isolated either from the spleen, mesenteric lymph nodes, colonic epithelium, or colonic patches of mice and processed into a single-cell suspension. These cells were subsequently stained with rat anti-mouse CD4, CD25 (BD Biosciences), CD73, and Foxp3 or hamster anti-mouse CD11c (eBioscience) at a $1: 250$ dilution in PBS. After incubating for $30 \mathrm{~min}$ at $4^{\circ} \mathrm{C}$ with the antibody cocktail, the cells were washed and resuspended in PBS. FoxP3 staining was performed using the eBioscience FoxP3-APC kit. Sample data were acquired using a FACScalibur with CellQuest software. Data files were analyzed using FlowJo software.

2.6. Histology. Hematoxylin and eosin (H\&E) staining was performed by the Cornell University College of Veterinary Medicine Core Histology lab on formalin fixed tissue samples. Immunohistochemistry and immunofluorescence were performed on OCT embedding tissue snap-frozen in liquid nitrogen-chilled methylbutane and sectioned into $5 \mu \mathrm{m}$ slices on a cryostat. Primary antibodies used were CD4, CD45, CD11c (hamster anti-mouse 1:30), and CD321 (JAM-A, rat anti mouse, $1: 100$ ). Secondary antibodies used were biotinylated goat anti-rat IgG and biotinylated goat anti-hamster $\operatorname{IgG}(1: 100)$. For immunohistochemistry, slides were treated with streptavidin-HRP followed by AEC and counterstained with hematoxylin. Immunofluorescence staining for CD321 was performed by treating with a $1: 200$ dilution of streptavidin-AF488 for 90 minutes at $37^{\circ} \mathrm{C}$ and then fixed in $1 \%$ formalin for 10 minutes.

2.7. Clinical Score and Histological Analysis. Changes in body weight were assessed as a percent change in body weight compared to baseline. A scoring system (from 0-4) was used to determine the presence of occult or overt blood 


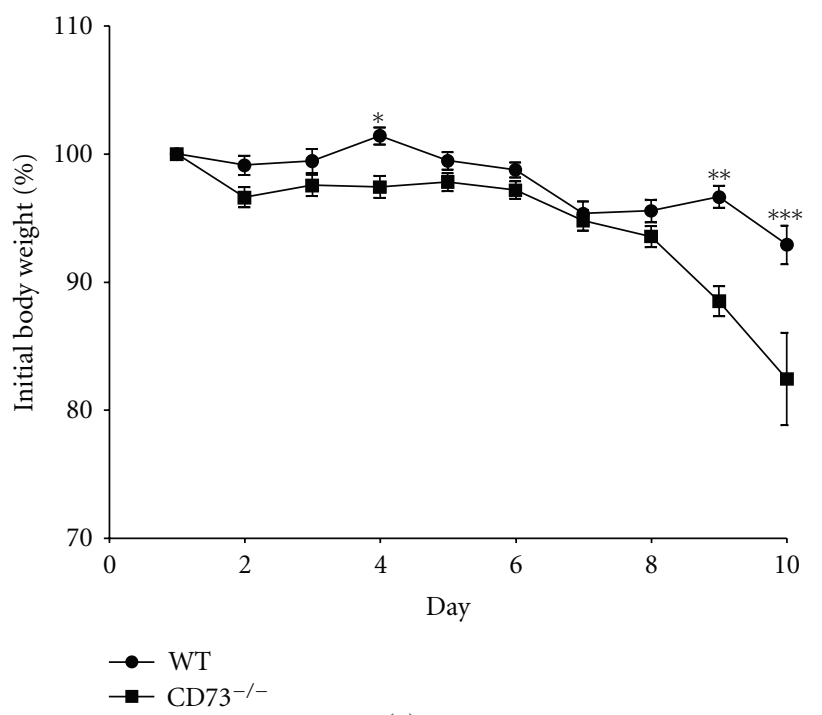

(a)

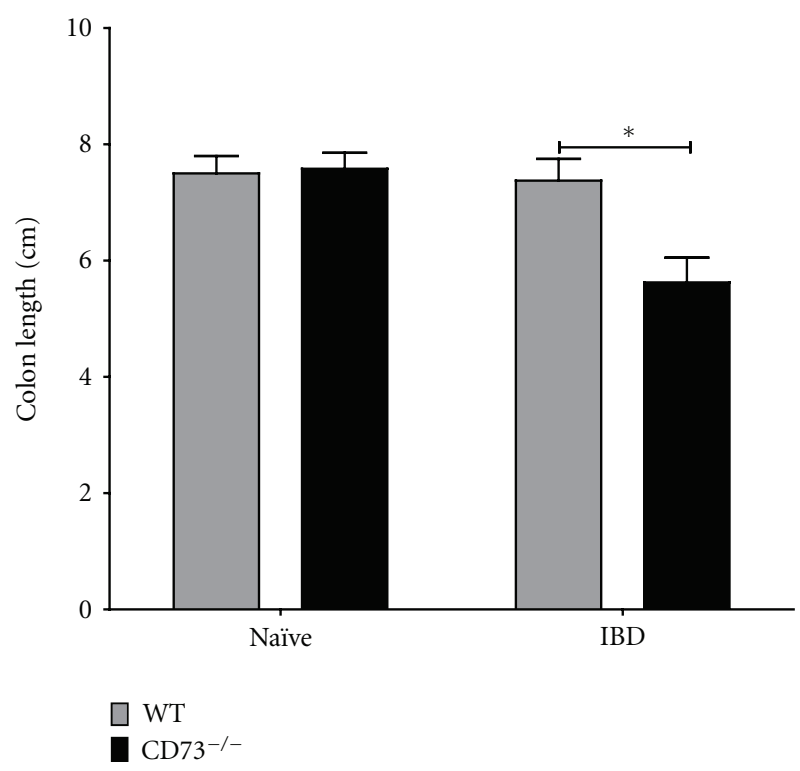

(c)

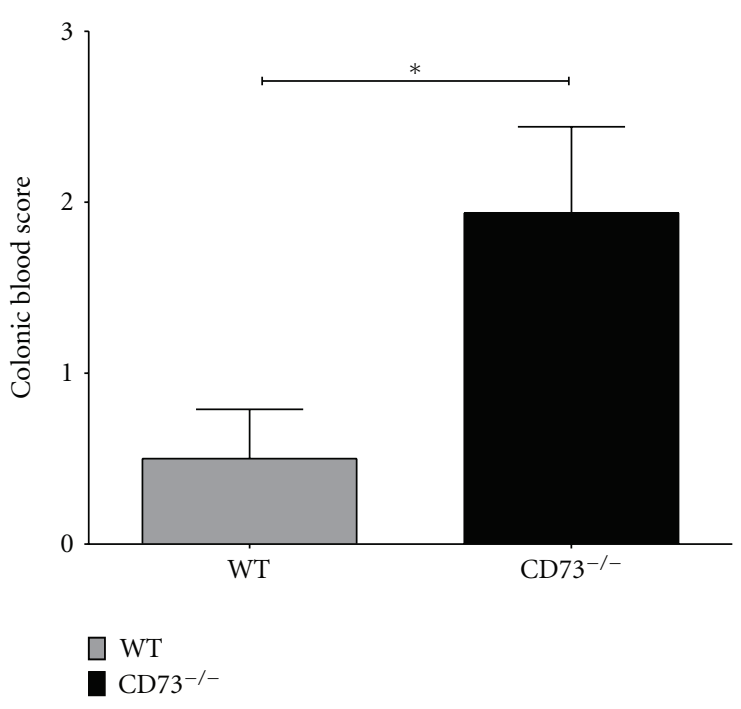

(b)
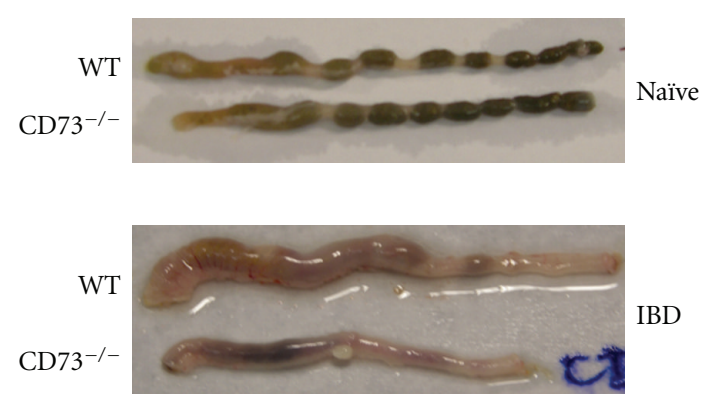

(d)

FIgURE 1: $\mathrm{CD}^{-/-}$mice develop more severe clinical signs of IBD than WT mice. (a) WT (circles) and CD73-/- (squares) mice were given $3 \%$ DSS in drinking water and weighed daily for 10 days. Results are represented as \% of initial weight $( \pm$ SEM, summary of 5 experiments, $\left.n=26,{ }^{*} P<0.05,{ }^{* *} P<0.01,{ }^{* * *} P<0.005\right)$. (b) Mean $\left( \pm \mathrm{SEM}, n=4,{ }^{*} P<0.05\right.$, representative of 5 experiments) colonic blood score is displayed $(0=$ no blood in colon; $1=$ blood in $25 \%$ of colon; $2=$ blood in $50 \%$ of colon; $3=$ blood in $75 \%$ of colon; $4=$ blood in $100 \%$ of colon). (c) Mean ( \pm SEM, $n=4,{ }^{*} P<0.05$, representative of 5 experiments) colon length $(\mathrm{cm})$ is displayed, along with (d) a representative photograph.

in the stool. Colonic inflammatory score was determined by the extent of inflammatory cell infiltrates $(0-3)$ and tissue damage (0-3). Scoring was performed in a blinded manner. Cell infiltration and tissue damage were added and the combined "colitis severity score" ranged from 0 to 6 (description in legends to Figures 2, 3 and 4).

In Figure 2, (a) histology of colons from WT (top panels) and $\mathrm{CD}^{-/-}$(bottom panels) mice treated with 3\% DSS in drinking water. Left two panels show hematoxylin and eosin (H\&E) stains displaying colonic epithelial crypt histopathology and appearance of granulomas (in $\mathrm{CD} 73^{-/-}$) mice. Right three panels show $\mathrm{CD} 4^{+}$cell (brown) infiltration in the colon. (b) Mean $( \pm$ SEM, $* * * * P<0.001, n=8)$ colonic inflammatory score is displayed. The scoring scale is comprised of two components: (i) inflammatory cell infiltrate (focus of inflammatory cells in the lamina propria $=1$, confluence of inflammatory cells $=2$, and transmural extension of the infiltrates $=3$ ); (ii) tissue damage (discrete lymphoepithelial lesions $=1$, mucosal erosion $=2$ and extensive mucosal damage and extension through deeper structures 


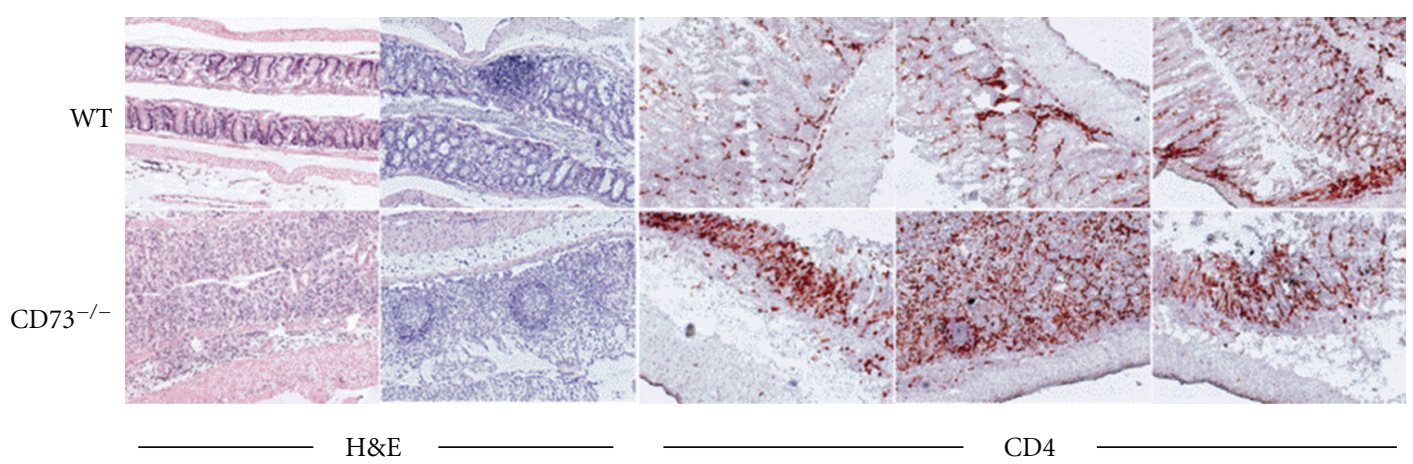

(a)

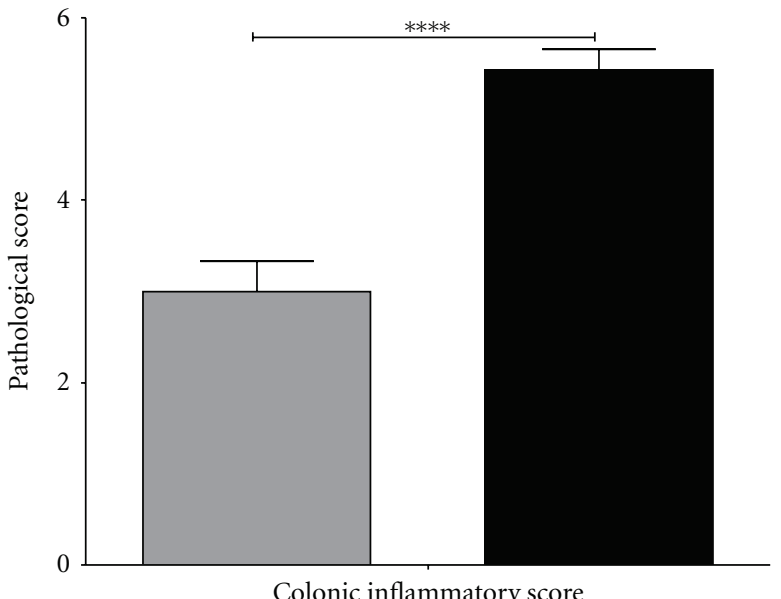

Colonic inflammatory score

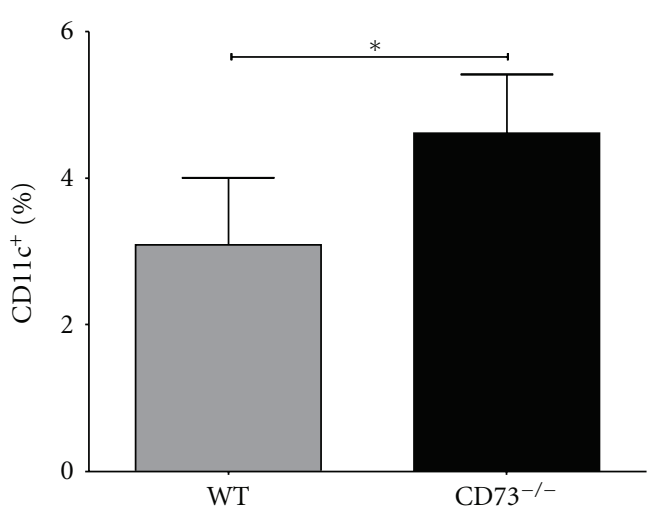

$\square \mathrm{WT}$ (b)

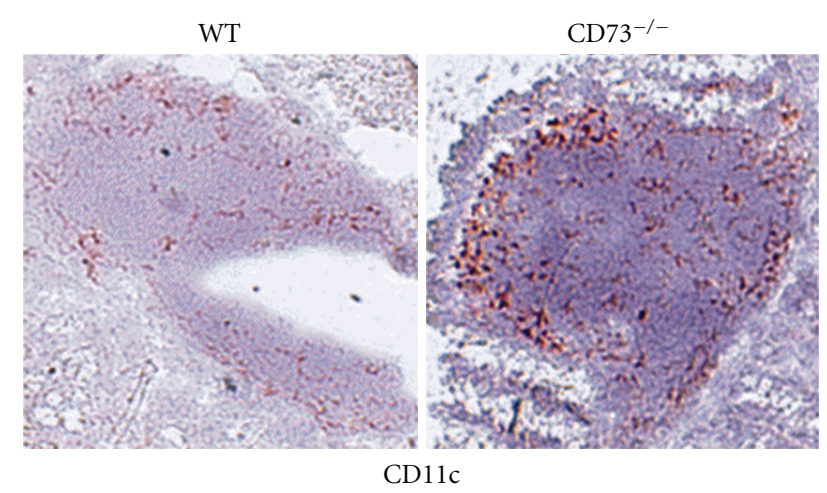

(d)

Figure 2: $\mathrm{CD}^{-1} 3^{-/}$mice display a higher degree of infiltration in the colon compared to WT mice.

of the bowel wall $=3$ ). The two scores (cell infiltration and cell damage) are added, and the combined histological colitis severity score ranges from 0 to 6 . (c) Colonic patches from WT and $\mathrm{CD}^{-1-}$ mice treated with $3 \%$ DSS in drinking water were isolated and stained for $\mathrm{CD} 11 \mathrm{c}$ and analyzed by FACS. Results are displayed as $\%$ of CD11 $\mathrm{c}^{+}$cells (data representative of 3 experiments). (d) Immunohistochemistry of colons from WT (left) and CD73 ${ }^{-/-}$(right) mice treated with 3\% DSS in drinking water. Sections show CD11c infiltration in the colons of mice. (e) IL- $1 \beta$ and TNF- $\alpha$ produced by lymphocytes from colonic patches of $\mathrm{CD} 73^{-/-}$ and WT mice after 24-hour incubation in medium without stimulation. Samples were analyzed by Bio-Plex instrument (from three different experiments, $n=15$ mice, ${ }^{*} P<0.05$, ${ }^{* *} P<0.01,{ }^{* * *} P<0.005, \mathrm{ND}=$ not detected).

In Figure 3, (a) $\mathrm{CD}^{+} \mathrm{CD}^{2} 5 \mathrm{RB}^{\text {high }} \mathrm{T}$ cells from WT (circles) and $\mathrm{CD}^{-/-}$(squares) were transferred into $\mathrm{rag}^{-1-}$ mice, which were monitored for 45 days. Results 


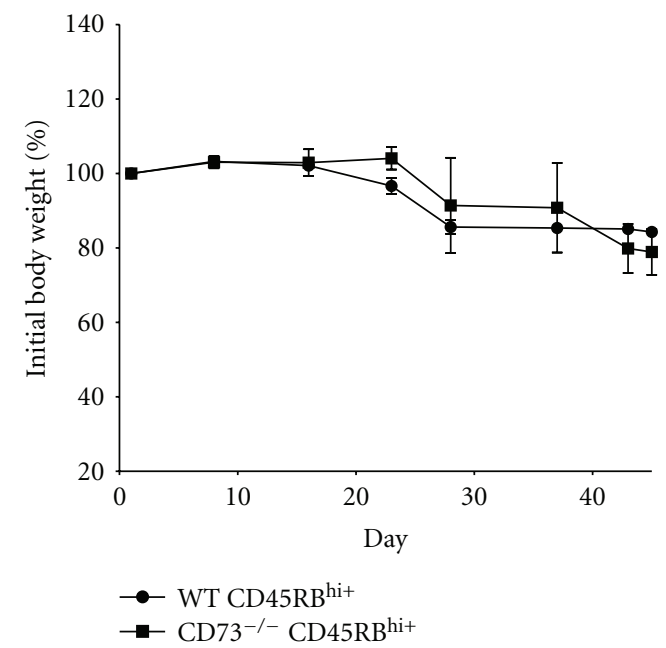

(a)

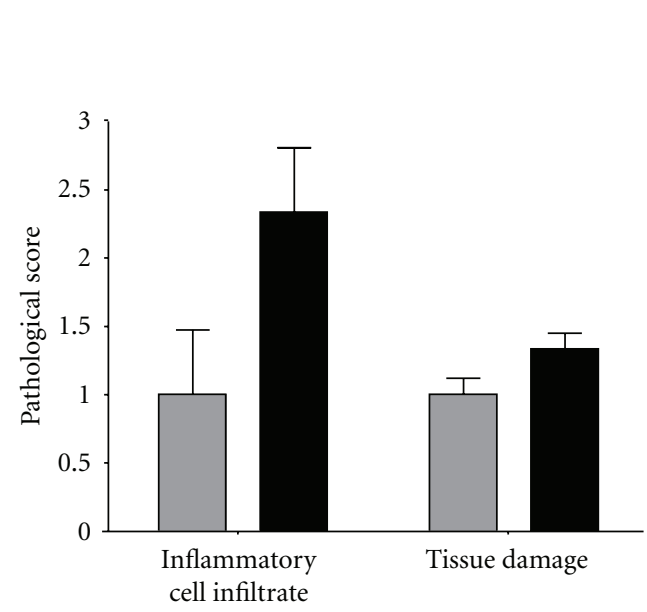

$\square$ WT

- $\mathrm{CD} 73^{-1-}$

(c)

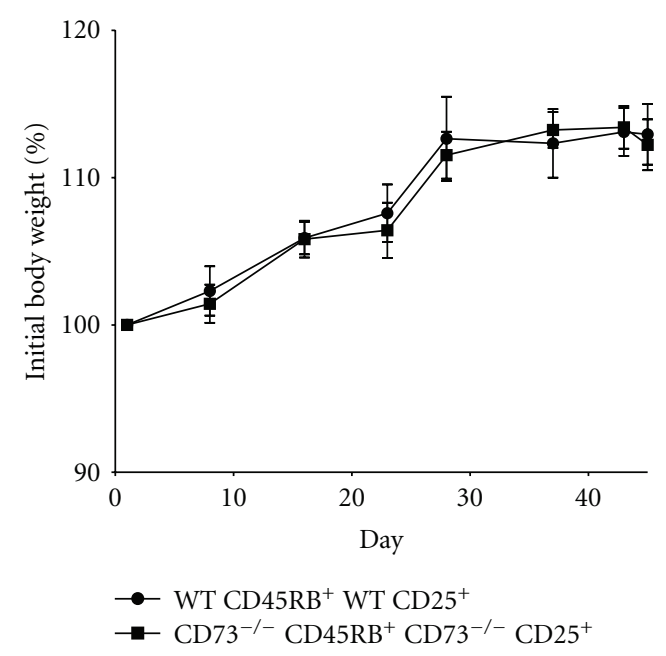

(e)
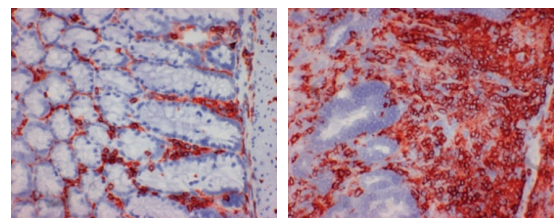

(ii)

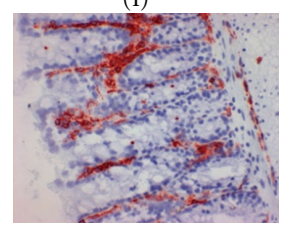

(iii)

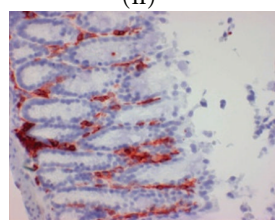

(iv)

(b)

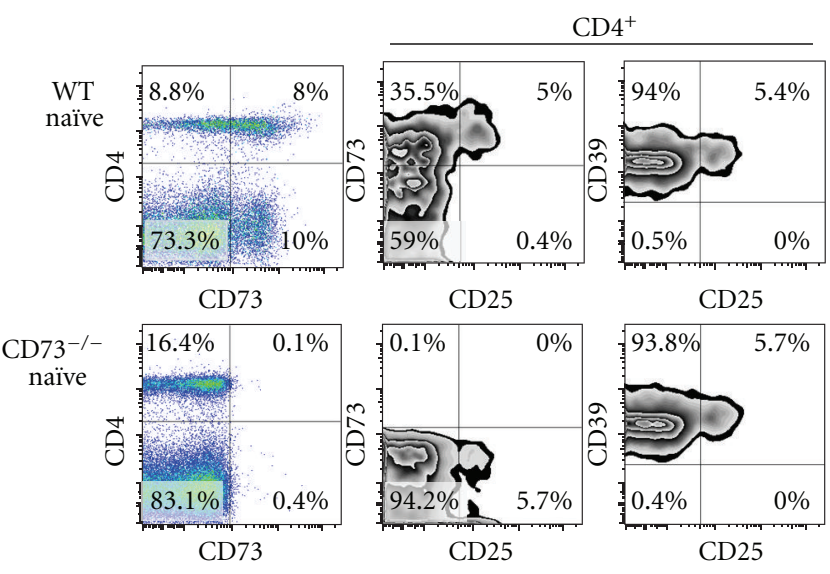

(d)

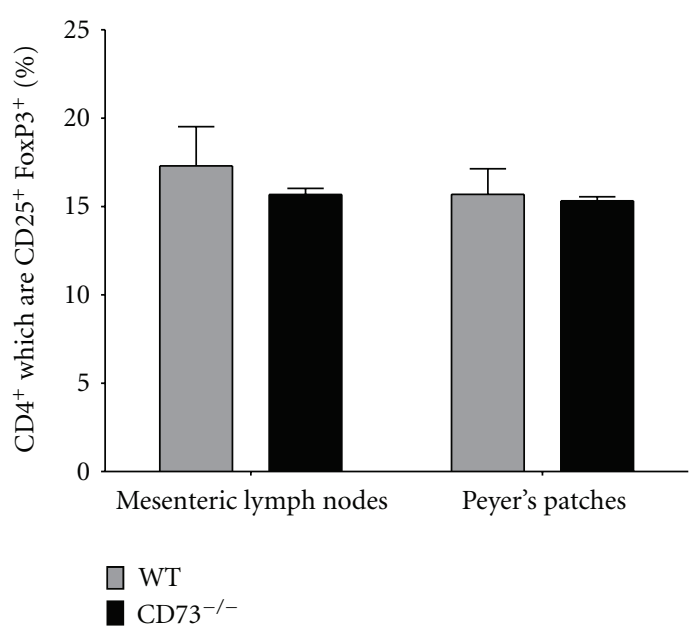

(f)

FigurE 3: $\mathrm{CD} 4^{+} \mathrm{T}$ cells from $\mathrm{CD}_{3} 3^{-/-}$mice transfer a similar degree of colitis compared to WT mice and show no defect in $\mathrm{T}_{\text {reg }}$ suppression of IBD. 

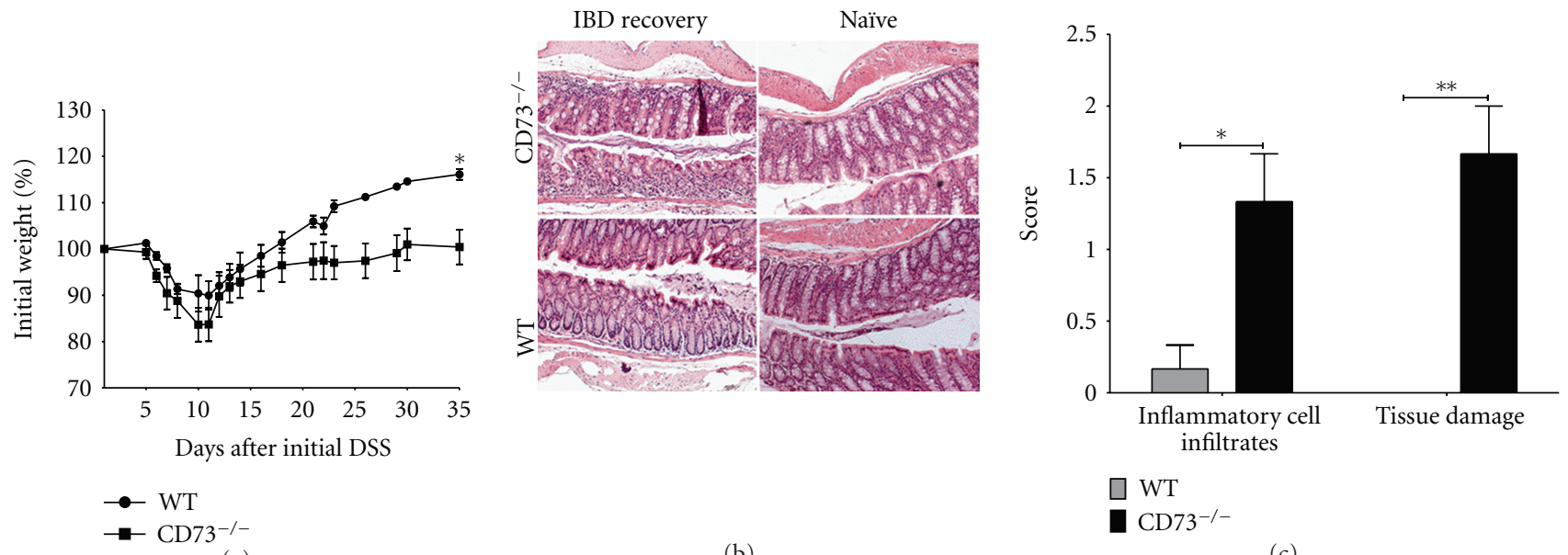

(a)

(b)

(c)
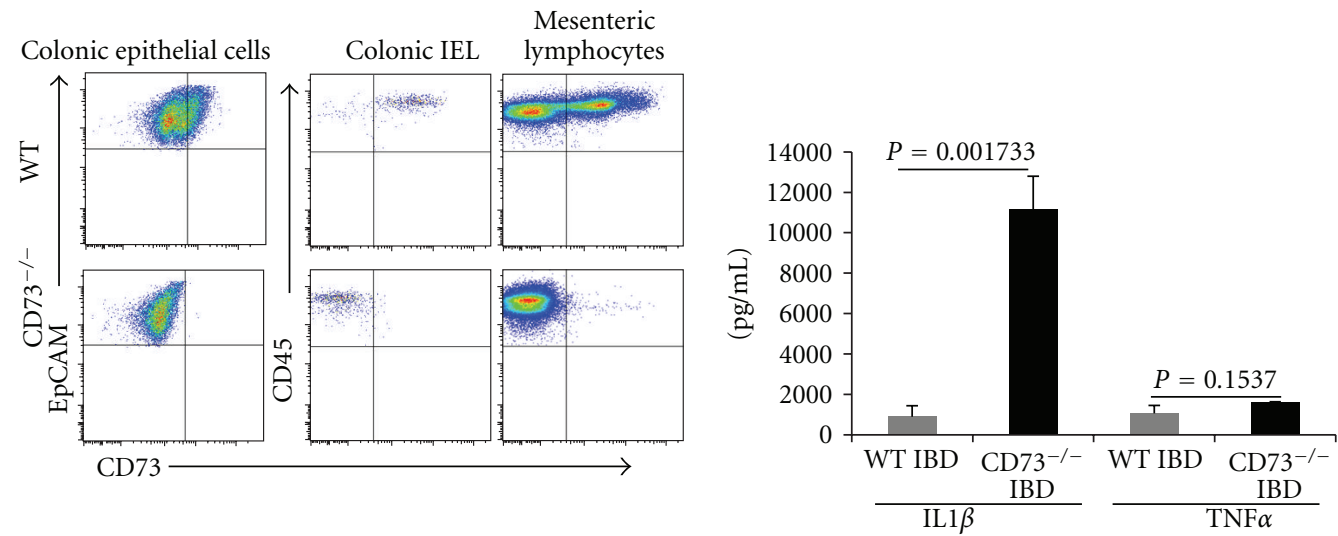

(d)

(e)

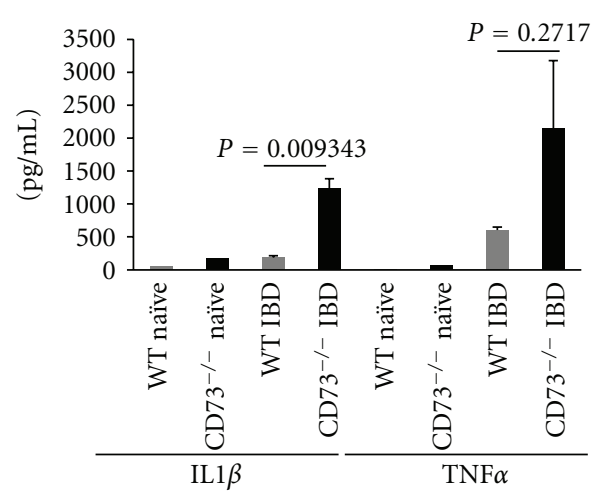

(f)

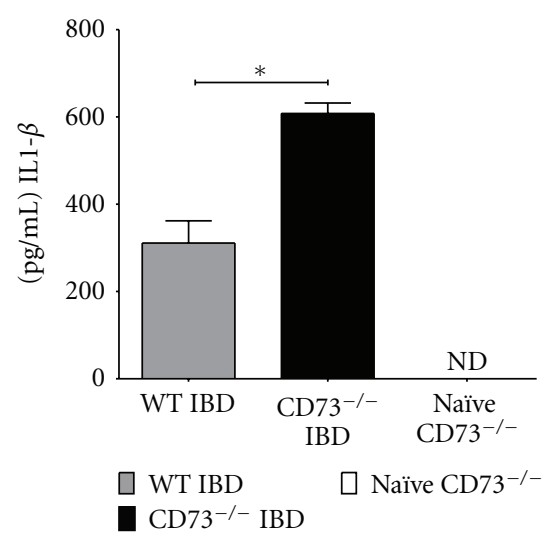

(g)

FIGURE 4: CD73 ${ }^{-/-}$mice exhibit ongoing inflammation and slower recovery from IBD compared to WT mice. (a) WT (circles) and CD73 ${ }^{-/-}$ (squares) mice were given 3\% DSS in drinking water and weighed daily for 35 days. DSS was removed at day 8 and replaced with drinking water. Results are represented as $\%$ of initial weight $\left( \pm \mathrm{SEM},{ }^{*} P<0.05\right.$, one of two representative experiments). (b) H\&E staining of colons from $\mathrm{CD} 3^{-/-}$(top) and WT (bottom) mice taken on day 35 (left) compared to naïve (right) mice. (c) Mean $\left( \pm \mathrm{SEM},{ }^{*} P<0.05, * * P<0.01\right)$ colonic inflammatory score is displayed ( $n=5$ mice). The scoring scale is comprised of two components: (i) inflammatory cell infiltrate (focus of inflammatory cells in the lamina propria $=1$, confluence of inflammatory cells $=2$, and transmural extension of the infiltrates $=$ 3); (ii) tissue damage (discrete lymphoepithelial lesions $=1$, mucosal erosion $=2$, and extensive mucosal damage and extension through deeper structures of the bowel wall = 3). (d) FACS analysis of CD73 expression on colonic epithelial cells from naïve WT (top left panel, $28 \%$ ) and $\mathrm{CD}^{-1-}$ (bottom left panel, 0\%) mice. Colonic epithelial cells identified with CD326/EpCam. Colonic IEL's identified with CD45 (middle panels, WT $87 \% \mathrm{CD}^{+}{ }^{+}$). Mesenteric lymph nodes shown as a positive control (right panels, WT 39\% CD73 ${ }^{+}$). (e) IL-1 $\beta$ and TNF $\alpha$ production in colon preparation isolated from WT and CD73-1- mice on day three of DSS treatment and (f) day eight of DSS treatment. (g) Colons isolated from WT and CD73 ${ }^{-/}$mice on day 22 after removal of DSS were cultured (in medium alone) for 24 hours and supernatant analyzed by Bio-Plex for IL- $1 \beta$. Results (mean \pm SEM, ${ }^{*} P<0.05$, representative of one experiment, $n=3$ mice per group) are presented as $\mathrm{pg} / \mathrm{mL}$ IL-1 $\beta$ produced. 
TABLE 1

\begin{tabular}{lll}
\hline Target gene & Forward $\left(5^{\prime}\right.$ to $\left.3^{\prime}\right)$ & Reverse $\left(5^{\prime}\right.$ to $\left.3^{\prime}\right)$ \\
\hline JAM-A & TCTCTTCACGTCTATGATCCTGG & TTTGATGGACTCGTTCTCGGG \\
Claudin 2 & GTACCCTTTTAGGACTTCCTGC & CCCACCACAGAGATAATACAAGC \\
A Catenin & TCTCTACTGCCACCAGCTCAAC & AAGCCATCCCCTGTGACTTCT \\
GAPDH & CCCCAATGTGTCCGTCGTG & GCCTGCTTCACCACCTTCT \\
TLR1 & GTCTCCCCACTTCATCCAGA & GCTTGTTCTTCTCTGTGGGC \\
TLR3 & GGTCCCCAGCCTTCAAAGAC & ACGAAGAGGGCGGAAAGGT \\
TLR4 & CAGGTGGAATTGTATCGCCT & CGAGGCTTTTCCATCCAATA \\
TLR5 & CCACCGAAGACTGCGATGA & GTGACCGTGCACAGGATGAA \\
TLR9 & ATG GTT CTC CGT CGA AGG ACT 1 & GAG GCT TCA GCT CAC AGG G \\
\hline
\end{tabular}

(5 mice/group, mean \pm SEM, representative of 3 experiments) are displayed as \% of initial weight. (b) CD45 staining of frozen colons from $\mathrm{rag}^{-/-}$mice 45 days after $\mathrm{T}$ cell transfer: (i) WT CD45RB ${ }^{+}$donor, (ii) $\mathrm{CD}^{-/-} \mathrm{CD}^{-15 \mathrm{RB}^{+}}$ donor, (iii) WT $\mathrm{CD}_{4} 5 \mathrm{RB}^{+}$and $\mathrm{WT} \mathrm{CD} 25^{+}$donors, and (iv) $\mathrm{CD}^{2} 3^{-/-} \mathrm{CD}_{45 \mathrm{RB}^{+}}$and $\mathrm{CD}^{-1-} \mathrm{CD} 25^{+}$donors. (c) Colonic inflammatory score is displayed with separate scores for inflammatory cell infiltrate (focus of inflammatory cells in the lamina propria $=1$, confluence of inflammatory cells $=2$ and transmural extension of the infiltrates $=3$ ), and tissue damage (discrete lymphoepithelial lesions $=1$, mucosal erosion $=2$, and extensive mucosal damage and extension through deeper structures of the bowel wall $=3$ ) ( $n=6$ mice, inflammatory cell infiltrate, \pm SEM, $P=0.05$, tissue damage, $P=0.4$ ). (D) CD25, CD73, and CD39 expression on $\mathrm{CD}^{+} \mathrm{T}$ cells from mesenteric lymph nodes and colonic patches of naïve WT and $\mathrm{CD} 73^{-/-}$mice. Lefthand panels show distribution of $\mathrm{CD} 73$ on $\mathrm{CD}^{+}$cells. Middle panels show distribution of iELs, and right panels are gated on $\mathrm{CD}^{+}$cells and show distribution of CD25/CD73 and $\mathrm{CD} 25 / \mathrm{CD} 39$ expression. (e) $\mathrm{CD} 4^{+} \mathrm{CD} 45 \mathrm{RB}^{\text {high }}$ and $\mathrm{CD}^{+}{ }^{+} \mathrm{CD} 25^{+}\left(\mathrm{CD} 45 \mathrm{RB}^{\mathrm{lo}}\right) \mathrm{T}$ cells from WT (circles) or $\mathrm{CD}^{-1-}$ (squares) were transferred into $\mathrm{rag}^{-/-}$mice. Results (mean \pm SEM, representative of 3 experiments) are displayed as \% of initial weight. (f) FoxP3 expression in colonic patches and mesenteric lymph nodes from $\mathrm{CD} 73^{-/-}$ versus WT mice (representative of two experiments).

2.8. Cytokine Analysis. For Figure 2, colonic patches were cultured overnight at $37^{\circ} \mathrm{C}$ in Bruff's media. For Figure 4, whole colons were isolated from DSS-treated and naïve $\mathrm{CD}^{-1-}$ and WT animals and cultured overnight at $37^{\circ} \mathrm{C}$ in Bruff's media. The culture supernatant was isolated and frozen at $-80^{\circ} \mathrm{C}$. Analysis of cytokine levels was performed using a Bio-Plex system.

2.9. Real-Time PCR. All data was generated using either the Thermo Scientific SYBR Green kit and the ABI 7500 RealTime PCR machine or the Kapa SYBR FAST qPCR kit and the Bio-Rad C1000 Real-Time PCR machine. Expression of all genes was standardized to expression of glyceraldehyde 3phosphate dehydrogenase (GAPDH) and relativised to WT expression of the gene in question or was compared to PGK1 (housekeeping gene) expression. Primers, whose sequences are shown in Table 1, were obtained from IDT.

2.10. Gastrointestinal Permeability. Briefly, mice were fasted for $3 \mathrm{hrs}$ and were rectally administered $200 \mu \mathrm{L}$ of $10 \mathrm{mg} / \mathrm{mL}$ $(0.1 \mathrm{mg} / \mathrm{g}$ body weight) $10 \mathrm{kDa}$ FITC-dextran (Invitrogen) in PBS [25]. After 1 hour, mice were bled via their submandibular vein, the whole blood spun at 2,000 $\times$ g for $5 \mathrm{~min}$, and the serum isolated. This isolation yielded approximately $150 \mu \mathrm{L}$ of serum per animal. Serum fluorescence was measured on a BioTek (Winooski, VT) Synergy 4 analyzer. FITC-Dextran concentration was calculated from standard curves generated by serially diluting FITC-Dextran.

2.11. Western Blotting. Western blot analysis as described in [26] was performed on colonic epithelial cells of $\mathrm{CD}^{-1-}$ and WT mice. Briefly, cells $\left(2 \times 10^{6}\right)$ were lysed in reducing SDS sample buffer followed by centrifugation at $18,000 \mathrm{~g}$ for $5 \mathrm{~min}$. Samples were boiled for 10 minutes after which equal amounts of total cell lysates were separated by 10\% SDSPAGE and electrophoresed onto PVDF (Millipore, Bedford, MA). Samples were incubated with Ab specific for dualphosphorylated (active) NF- $\kappa$ B P65 subunit used at the concentrations recommended by the manufacturer (Cell Signaling Technology, Beverly, MA) in 5\% BSA in Tris buffered saline, $0.1 \%$ Tween 20 overnight at $4^{\circ} \mathrm{C}$.

\section{Results}

3.1. CD73-/- Mice Develop More Severe IBD Than WT Mice. Since CD73 catalyzes the formation of extracellular immunosuppressive adenosine from damaged cells during inflammation and is highly expressed on colon tissue [1619], we investigated the impact of a lack of CD73 in the intestinal mucosa. To do this, we induced IBD in $\mathrm{CD}^{-1-}$ and WT mice by oral treatment with $3 \%$ DSS in drinking water. DSS-induced colitis resulted in significant weight loss, epithelial damage, and robust colonic inflammation (Figure 1). Daily monitoring of IBD revealed that $\mathrm{CD} 3^{-/-}$mice developed markedly more severe clinical signs of IBD, including diarrhea and dehydration (data not shown), when compared to WT mice (Figure 1). Frequently, disease had to be aborted before the duration of the 10 
day protocol because greater than $50 \%$ of $\mathrm{CD}^{-1-}$ mice exhibited substantial weight loss and severe rectal bleeding. This was accompanied by more pronounced weight loss (Figure 1(a)), higher colonic blood scores (Figure 1(b)), and shorter colon length (Figure 1(c)).

Histological analyses of the colons of DSS-treated $\mathrm{CD}_{73^{-/}}$mice revealed extensive destruction of colonic epithelial architecture, including epithelial crypt destruction, massive immune cell infiltration into the lamina propria, and the appearance of granulomas (in 30\% of mice), and an overall increase in colon inflammatory score compared to WT mice (Figures 2(a) and 2(b)). These immune cell infiltrates consist of $\mathrm{CD}^{+} 5^{+}$cells (a general marker for leukocytes, data not shown) with a substantial number being $\mathrm{CD}^{+} \mathrm{T}$ cells (Figure 2(a)). FACS analysis of colonic patches (lymphoid aggregates from colon) also revealed a higher percentage of CD $11 c^{+}$dendritic cells in $\mathrm{CD}^{-/-}$mice compared to WT mice (Figures 2(c) and 2(d)).

We next determined the cytokine profile of infiltrating leukocytes isolated from the colon of DSS-treated CD73 $3^{-/-}$ and WT mice. Cells from colonic patches of $\mathrm{CD}^{-1-}$ mice produced higher levels of IL- $1 \beta$ compared to those from WT mice (data not shown). There was no significant difference in TNF- $\alpha$, IFN- $\gamma$, IL-17, IL-4, or IL-10 levels between WT and $\mathrm{CD}^{-/-}$mice (data not shown). The increase in IL-1 $\beta$ suggests that infiltrating inflammatory cells into the colon are capable of contributing to the severe IBD in $\mathrm{CD} 73^{-/-}$mice.

3.2. $C D 45 R B^{\text {high }} C D 4^{+}$Cells from $C D 73^{-1-}$ Mice Transfer Similar Degree of Colitis as WT Mice. Due to the immunoregulatory effects of localized CD73-driven adenosine production, we next determined if the severe IBD phenotype observed in DSS-treated CD73 ${ }^{-/-}$mice was due to a more proinflammatory nature of the $\mathrm{CD} 4^{+} \mathrm{T}$-cell population. To address this question, we induced IBD by transferring $\mathrm{CD} 4^{+} \mathrm{CD} 45 \mathrm{RB}^{\text {high }}$ $\mathrm{T}$ cells into $\mathrm{rag}^{-/-}$recipients [27]. IBD induced by this method involves differential activation of $\mathrm{T}_{\mathrm{H}^{-1}}$ cells and can be inhibited by cotransfer of $\mathrm{CD} 4^{+} \mathrm{CD} 45 \mathrm{RB}^{\text {low }}$ (consisting of $\mathrm{CD}_{2} 5^{+} \mathrm{T}$ regulatory cells) cells into $\mathrm{rag}^{-/-}$recipients [28]. $\mathrm{CD}^{+} \mathrm{CD}^{2} 5 \mathrm{RB}^{\text {high }}$ cells were isolated from spleens of naïve WT or $\mathrm{CD}^{-1} 3^{-/}$mice and adoptively transferred into $\mathrm{rag}^{-/-}$recipients. Recipients of $\mathrm{CD}^{-/-} 3^{-1} 4^{+} \mathrm{CD} 45 \mathrm{RB}^{\text {high }}$ $\mathrm{T}$ cells exhibited a similar weight loss pattern to those recipients of WT $\mathrm{CD}^{+}{ }^{+} \mathrm{CD} 45 \mathrm{RB}^{\text {high }} \mathrm{T}$ cells (Figure 3(a)). Histological analysis of colons revealed $\mathrm{rag}^{-/-}$mice that received $\mathrm{CD} 4^{+} \mathrm{CD} 45 \mathrm{RB}^{\text {high }}$ cells from $\mathrm{CD} 73^{-/-}$mice had significantly more immune cell infiltration in the lamina propria compared to recipients of $\mathrm{CD} 4^{+} \mathrm{CD} 45 \mathrm{RB}^{\text {high }}$ cells from WT mice (Figures 3(b) and 3(c)). However, the resultant colonic epithelial damage compared between recipients of WT and $\mathrm{CD} 3^{-/-} \mathrm{CD} 4^{+} \mathrm{CD} 45 \mathrm{RB}^{\text {high }}$ donor cells is not statistically significant (Figures 3(c) and see S1 in supplementary material available online at doi:101155/2012/260983). This suggests that the inflammatory immune cells infiltrating the large intestine is not the sole cause of the very severe IBD observed in $\mathrm{CD} 73^{-/-}$mice.

Recent studies have indicated that CD73 and CD39 are important for immune suppression by $\mathrm{T}$ regulatory cells
[20]. We therefore asked whether $\mathrm{CD}^{+} \mathrm{T}$ regulatory $\left(\mathrm{T}_{\text {reg }}\right)$ cells from $\mathrm{CD}^{-/-}$mice were defective in their ability to suppress IBD. In naïve WT mice, fifty percent of $\mathrm{CD} 4^{+} \mathrm{T}$ cells express CD73 (Figure 3(d)) and all CD $4^{+} \mathrm{CD} 25^{+}$cells express both CD73 and CD39 (Figure 3(d)). CD4 ${ }^{+}$CD45RB ${ }^{\text {high }}$ and $\mathrm{CD}^{+} \mathrm{CD}^{2} 5^{+}\left(\mathrm{CD} 45 \mathrm{RB}^{\mathrm{lo}}\right)$ cells from spleens of naïve WT mice were cotransferred into $\mathrm{rag}^{-/-}$recipients. Similarly, naïve $\mathrm{CD} 4^{+} \mathrm{CD} 45 \mathrm{RB}^{\text {high }}$ and $\mathrm{CD} 4^{+} \mathrm{CD} 25^{+}\left(\mathrm{CD} 45 \mathrm{RB}^{\text {lo }}\right)$ cells from $\mathrm{CD}_{3} 3^{-/}$mice were cotransferred into $\mathrm{rag}^{-/-}$recipients. $\mathrm{Rag}^{-/-}$mice that received $\mathrm{CD} 73^{-/-} \mathrm{CD} 4^{+} \mathrm{CD} 45 \mathrm{RB}^{\text {high }}$ and $\mathrm{CD}^{+} \mathrm{CD} 25^{+}$cells developed no clinical signs of IBD and showed a similar weight-gain pattern to $\mathrm{rag}^{-/-}$mice receiving $\mathrm{WT} \mathrm{CD}^{+} \mathrm{CD} 45 \mathrm{RB}^{\text {high }}$ and $\mathrm{CD} 4{ }^{+} \mathrm{CD} 45 \mathrm{RB}^{\text {lo }} \mathrm{CD} 25^{+}$ cells (that also showed no signs of IBD) (Figure 3(e)). Further, similar to WT mice, $\mathrm{CD} 73^{-/-}$mice harbor similar frequency of $\mathrm{CD}^{+}{ }^{+} \mathrm{FoxP}^{+} \mathrm{T}$ cells in colonic patches (lymphoid follicles) and mesenteric lymph nodes compared to those of WT mice (Figure 3(f)) (also in peripheral lymphoid organs [29]). These results indicate that neither the numbers nor the function of $\mathrm{CD} 4^{+}$Treg cells from $\mathrm{CD} 73^{-/-}$mice is significantly altered and thus is not the only contributing factor in the severe IBD in $\mathrm{CD} 73^{-/-}$mice. From these studies we conclude that a lack of CD73 expression on $\mathrm{CD} 4{ }^{+} \mathrm{T}_{\text {reg }}$ cells did not majorly hamper their ability to suppress IBD.

\section{3. $\mathrm{CD}^{-1}{ }^{-/}$Mice Exhibit Ongoing Inflammation and Slower} Recovery Than WT Mice. Under normal conditions, WT mice can recover from colitis once DSS treatment is removed [24]. To determine whether $\mathrm{CD} 73^{-/-}$mice can recover from DSS-induced colitis we replaced DSS with drinking water on day eight in both WT and $\mathrm{CD}^{2} 3^{-1-}$ mice and monitored their body weight as an indication of disease alteration. $\mathrm{CD}^{-/-}$mice recovered at a slow rate following the removal of DSS from their drinking water, regaining their initial body weight 22 days after DSS removal (Figure 4(a)). This was in sharp contrast to WT mice that regained their initial body weight seven days after the removal of DSS and gained an additional $20 \%$ of their initial body weight by 22 days after T DSS removal (Figure 4(a)). Examination of colon pathology of WT mice after day 22 showed full recovery: colonic architecture showed little to no cell infiltration, no tissue damage, and normal looking epithelial crypts and goblet cells (Figures 4(b) and 4(c)). While $\mathrm{CD}^{-1-}$ mice (day 22) exhibited significantly reduced colonic pathology compared to that observed during DSS treatment, they still show modest cell infiltration, some epithelial hyperplasia, and noticeable crypt destruction (Figures 4(b) and 4(c)), indicating prolonged or ongoing inflammation illustrated by the colonic inflammatory score (Figure 4(c)).

3.4. Increased $I L-1 \beta$ and TNF- $\alpha$ Production in Colonic Epithelium of $\mathrm{CD}^{-1-}$ Compared to WT Mice. While inflammatory immune cells lacking CD73 play an important role in IBD pathogenesis in $\mathrm{CD}^{-/-}$mice (Figure $3(\mathrm{~b})$ ), it is apparent that they are not the only contributing factor that result in the very severe IBD. We next focused our attention on the colonic epithelium that is comprised of a single layer of intestinal epithelial cells that forms a physical as well as 
a chemical barrier between the host and the microbial community [30]. FACS analysis of colonic epithelial cells from naïve WT mice, double stained with an epithelial marker plus CD73, showed that about $40 \%$ of epithelial cells expressed CD73 (including intraepithelial lymphocytes (iELs) which make up about $10 \%$ of $\mathrm{CD}^{+} 3^{+}$cells) (Figure $4(\mathrm{~d})$ ).

We next focused on the colon in $\mathrm{CD}_{73^{-/}}$mice. We reasoned that the lack of $\mathrm{CD} 73$ expression on the colonic epithelium must contribute significantly to the severe IBD, since the immune cells lacking CD73 cannot recapitulate the severe colitis in $\mathrm{CD}_{73}^{-/-}$mice. The intestinal epithelium closely interacts with underlying mucosal immune cells to control the immune response $[2,31]$. The intestinal epithelium and its products determine whether the underlying immune status is suppressive or inflammatory. Damage or activation of the epithelial barrier results in production of inflammatory mediators by immune cells and epithelial cells [8]. We hypothesized that the lack of CD73 expression on colonic epithelial cells might contribute to the heightened proinflammatory conditions in IBD in $\mathrm{CD}^{-/-}$mice. We isolated colons of WT and $\mathrm{CD}_{73^{-/-}}$mice over the course of DSS treatment, including the period after DSS removal, cultured them in media overnight, and analyzed supernatants for cytokines by ELISA. We focused specifically on IL- $1 \beta$ and TNF- $\alpha$, as these cytokines are implicated in colitis both in mice and humans [32]. Further, extracellular adenosine is a potent regulator of proinflammatory cytokines including IL- $1 \beta$ and TNF- $\alpha$ [14]. Colons from CD73-/mice produced dramatically higher levels of IL- $1 \beta$ (more than 10-fold) and with slight increase in TNF- $\alpha$ on day 3 of DSS treatment compared to WT (Figure 4(e)). By day 8 of DSS treatment, $\mathrm{CD} 73^{-/-}$mice consistently produced significantly higher levels of these cytokines compared to WT mice (Figure 4(f)). Furthermore, supernatants from colons isolated after DSS removal (day 22) show significantly higher levels of IL- $1 \beta$ (similar to day 8 of DSS, but not TNF- $\alpha$ ) observed in CD73 ${ }^{-1-}$ mice (Figure $4(\mathrm{~g})$ ). IL- $1 \beta$ and TNF- $\alpha$ are potent proinflammatory factors that stimulate proliferation, apoptosis, phagocytosis, and transmigration of cells across epithelial and endothelial barriers as well as activate innate receptors on innate immune and epithelial cells [33]. The increased production of IL- $1 \beta$ and TNF- $\alpha$ is tightly correlated with IBD severity and tissue destruction in animals and human patients [1] and is consistent with the severe colitis and apparent lack of resolution of the inflammatory process in $\mathrm{CD} 73^{-/-}$mice.

3.5. Increased Activation of NF- $\kappa B$ in $C D 73^{-/-}$Mice Compared to WT Mice. IL- $1 \beta$ induces the phosphorylation of $\mathrm{I} \kappa \mathrm{B}$ resulting in its degradation and the activation of NF- $\kappa B$ [34]. The constitutive activation of NF- $\kappa \mathrm{B}$ is associated with aberrant expression of proinflammatory genes induced by cytokines such as IL-1 $\beta$ and is linked to the pathogenesis of IBD in both human and mice [35]. Adenosine is a potent regulator of IL- $1 \beta$, and IL-1 $\beta$ can increase the expression of the $\mathrm{A}_{2 \mathrm{~A}}$ adenosine receptor [36]. Further, adenosine is a negative regulator of NF- $\kappa \mathrm{B}$ activation in human intestinal epithelial cells [36]. Thus, we hypothesize that constitutive production of IL-1 $\beta$ in $\mathrm{CD}^{-/-}$mouse colonic epithelia (including intraepithelial lymphocytes) even after DSS removal may cause constitutive activation of NF- $\kappa$ B. To investigate this, we isolated colonic epithelial cells from WT and $\mathrm{CD} 73^{-1-}$ mice over the course of IBD and tested them for presence of NF$\kappa \mathrm{B}$ activity. Figure $\mathrm{S} 2$ shows that, at various disease intervals, $\mathrm{NF}-\kappa \mathrm{B}$ p65 protein is augmented in colonic epithelial cells in $\mathrm{CD}^{-/-}$compared to WT mice. These findings suggest that the lack of extracellular adenosine may result in prolonged $\mathrm{NF}-\kappa \mathrm{B}$ activity after the inflammatory trigger (DSS) is removed. This inflammatory program, through constitutive production of IL- $1 \beta$, can promote a proinflammatory feedback loop and a vicious inflammatory cycle.

3.6. Increased Intestinal Inflammation Is Associated with Increased Intestinal Permeability and Decreased Expression of Tight-Junction Associated Proteins in the Colons of $C D 73^{-1-}$ Mice. In IBD patients and animal models of IBD, increased inflammation strongly correlates with an increase in intestinal permeability and vice versa $[37,38]$. To determine if intestinal barrier permeability is altered, we examined the barrier integrity in $\mathrm{CD}_{73^{-/-}}$and WT mice by treating mice rectally with FITC-Dextran and measuring its concentration in sera one hour later. As shown in Figure 5(a), CD73-/mice exhibit significant increase in gastrointestinal permeability compared to WT. The protective barrier function of the intestinal epithelium is regulated by intercellular tight junctions that seal the space between epithelial cells [31]. Tight junction molecules are comprised of occludins, claudins, and JAM proteins [31]. Further, JAM-A/JAM-1 has been shown to be critical in the maintenance of epithelial barrier permeability, as $\mathrm{JAM}^{-\mathrm{A}^{-/}}$mice have increased leukocyte infiltration and increased mucosal barrier permeability to macromolecules in the intestinal mucosa [39]. We analyzed mRNA transcript levels of several junction molecules that are associated with tight-junction stability to determine if the loss of these factors could be responsible for the destruction of the colonic architecture observed in DSStreated $\mathrm{CD}_{73^{-/-}}$mice. We observed a significant decrease in the mRNA levels of JAM-A, $\alpha$-Catenin, and Claudin 2 in the colons of $\mathrm{CD}^{-/-}$mice compared to WT mice (Figure 5(b)). Furthermore, immunofluorescence staining with anti-JAM-A antibody shows JAM-A protein expression is decreased at the borders of epithelial cells in naïve CD73-/mice, while expression is localized to the plasma membrane in naïve WT mice (Figure 5(c)). These findings further demonstrate that extracellular adenosine is important in regulation and maintenance of intestinal barrier integrity.

3.7. TLR9 Is Upregulated in Colons of $C D 73^{-/-}$Mice during $I B D$. To further evaluate the status of the colonic epithelia and their ensuing inflammatory state, we next focused on Toll-like receptors (TLRs) [40]. We hypothesize that the ongoing inflammation in $\mathrm{CD}^{-1-}$ mice is due to a breakdown of the intestinal epithelial barrier that leads to leakage of luminal antigens into the lamina propria and activation of innate receptors. Intestinal epithelial cells express a spectrum of Toll-like receptors (TLRs), recognize and respond to microbial products (MAMP/PAMPS), and 

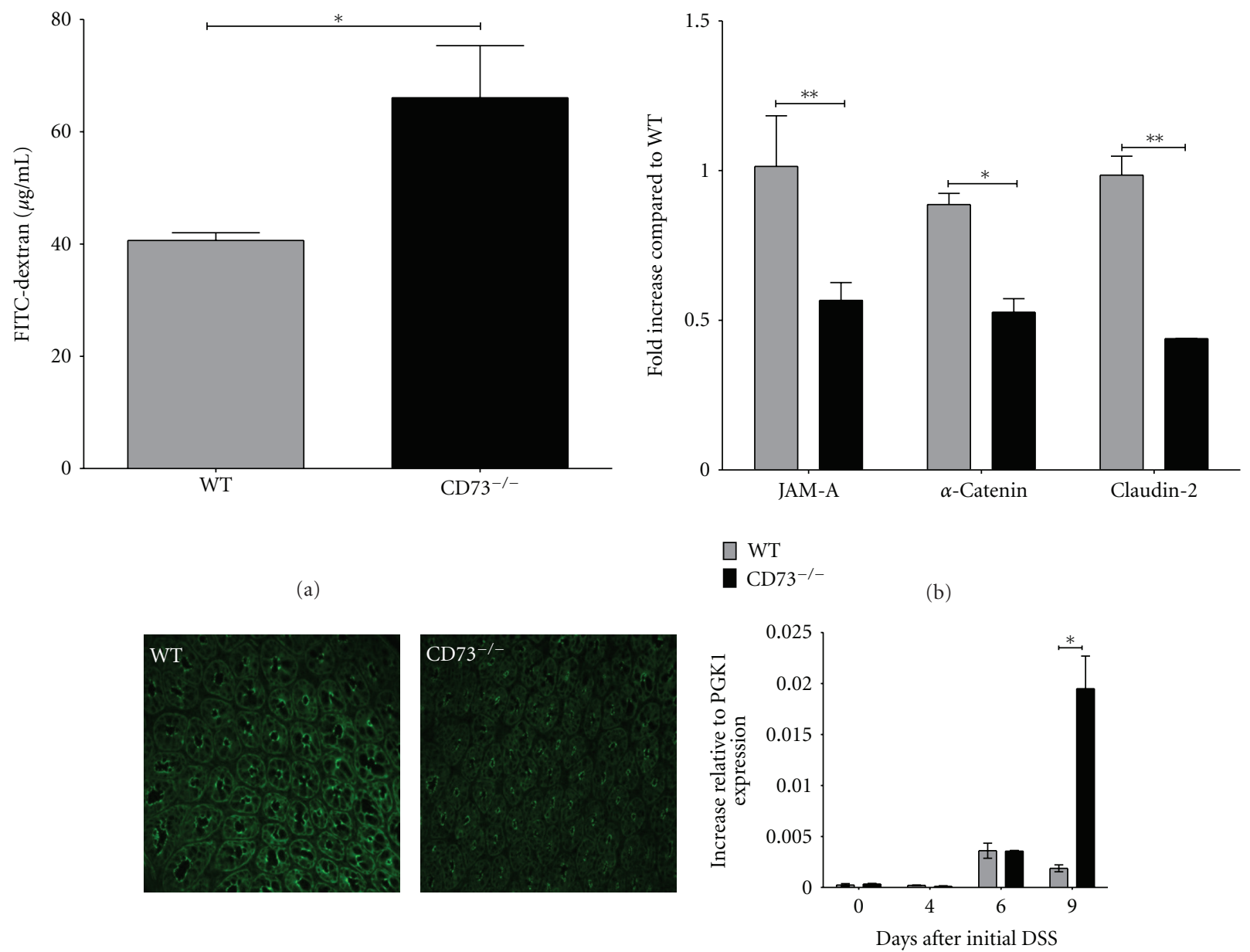

$\square \mathrm{WT}$
$\mathrm{CD} 73^{-/-}$

(c)

(d)

FIGURE 5: Upregulation of TLR9 in CD73-/- decreased expression of tight-junction associated proteins observed in the colons of CD73 ${ }^{-/-}$ mice compared to WT mice. (a) Colonic permeability was determined in WT and CD73 ${ }^{-1}$ mice. Serum concentrations of FITC-Dextran (MW 10,000) in WT (gray bar) and CD73-1- (black bar) mice were obtained following rectal administration of 10 KDa FITC-Dextran $(0.5 \mathrm{mg} / \mathrm{Kg})$ and measuring FITC-Dextran in the blood 1 hour later. Results are expressed as mean $\left.\pm \mathrm{SEM}, n=5,{ }^{*} P<0.05\right)$. Results are expressed as (mean \pm SEM, $n>3, * P<0.05$ ) relative fluorescence compared to WT. (b) Colons of WT (gray bars) and CD73 ${ }^{-/-}($black bars) were analyzed for mRNA expression of the adhesion molecules JAM-A, $\alpha$ Catenin, and Claudin-2. Results are expressed as (mean \pm SEM, $n=3, * P<0.05, * * P<0.01)$ fold increase in CD73 ${ }^{-1-}$ compared to WT. (c) Fluorescent microscopy of colons from naïve WT (left panel) and $\mathrm{CD}_{3}{ }^{-1-}$ (right panel) mice stained for JAM-A (green). (d) Colons were isolated from CD73 ${ }^{-/}$or WT mice over the course of IBD and analyzed for TLR9 mRNA expression by real-time PCR. Results are presented as TLR9 expression level relative to the housekeeping gene PGK1. (Representative of 3 experiments.)

can trigger inflammatory responses by mucosal immune cells [41]. To determine if the lack of CD73 expression on the colon results in increased expression of TLRs, we analyzed colons of IBD WT and $\mathrm{CD} 73^{-/}$mice by quantitative PCR analysis for mRNA expression. WT mice expressed background mRNA levels of a few TLRs, while other TLRs are not detected (Figure S3). In stark contrast, $\mathrm{CD} 73^{-/-}$ mice express more than 10-fold higher levels of TLR9 and just above background levels of TLR 3 and 5 (Figure S3). To determine the onset of TLR9 expression over the course of DSS treatment, we analyzed colons at different time points during IBD. We observed consistent increase in TLR9 expression in the latter stages of IBD (Figure 5(d)). These findings strongly support the idea of a more activated and proinflammatory state of the colonic epithelium in $\mathrm{CD}_{7} 3^{-/-}$ mice compared to WT mice.

\section{Discussion}

The goal of this study was to determine the role of extracellular adenosine in the regulation of intestinal inflammation. We demonstrate that mice lacking CD73 (and thus unable to adequately synthesize extracellular adenosine) exhibit severe 
colitis induced by DSS treatment. This finding is consistent with previous studies that showed $\mathrm{CD}^{-/-}$mice presented a more severe IBD induced by trinitrobenzene sulfonate (TNBS) administration than their WT counterparts [11]. In this study, $\mathrm{CD} 73^{-/-}$mice were found deficient in INF- $\alpha$, which may be important for regulating colonic inflammation. Here, we demonstrate that $\mathrm{CD} 73^{-/-}$mice are unable to resolve inflammation even after the removal of DSS. Compared to WT mice, colonic epithelia from $\mathrm{CD} 73^{-/-}$ mice produced consistently high levels of IL- $1 \beta$ and TNF$\alpha$ that correlate with increased NF- $\kappa \mathrm{B}$ and TLR9 expression and resultant gastrointestinal permeability. In this study, we demonstrate that heightened inflammation, induced by aggressive inflammatory immune cells, activated inflammatory colonic epithelial cells and increased intestinal barrier permeability result in severe unresolved DSS-induced colitis in mice lacking CD73. Similar outcomes from previous studies demonstrate that $\mathrm{CD}^{-/-}$mice presented more severe IBD, while these two studies use different approaches.

$\mathrm{CD}^{-1-}$ mice exhibit massive immune cell infiltration into the colon. The infiltrating cells are comprised primarily of $\mathrm{CD}^{+}{ }^{+} \mathrm{T}$ cells and dendritic cells. These $\mathrm{CD} 4^{+} \mathrm{T}$ cells in $\mathrm{CD}^{-1} 3^{-1}$ mice produced high levels of the proinflammatory cytokines IL- $1 \beta$ and TNF- $\alpha$, which are known to play a major role in the pathogenesis of IBD in humans and mice. However, adoptive transfer of naïve $\mathrm{CD} 4{ }^{+} \mathrm{CD} 45 \mathrm{RB}^{\text {high }}$ (inducer) $\mathrm{T}$ cells from $\mathrm{CD} 73^{-/-}$mice into naive $\mathrm{rag}^{-/-} \mathrm{cd} 73^{+/+}$recipients shows that while these mice developed severe colitis, the extent of the tissue damage was not dramatically different when compared to recipients that received $\mathrm{CD}^{+} \mathrm{CD} 45 \mathrm{RB}^{\text {high }} \mathrm{T}$ cells from $\mathrm{WT}$ mice. These findings suggest that the infiltrating immune cells are not the only cause of the severe IBD in $\mathrm{CD} 73^{-/-}$mice. Furthermore, cotransfer of regulatory $\mathrm{T}$ cells from either $\mathrm{WT}$ or $\mathrm{CD} 73^{-/-}$ mice prevented weight loss and intestinal pathology to an equal degree. Thus, CD4+Treg cells lacking CD73 are not defective in their ability to suppress IBD and therefore are not a major contributor to the severe IBD in $\mathrm{CD} 73^{-/-}$mice. From these observations, we determined that, while the lack of CD73 expression on immune cells contributed to the pathogenesis of IBD, this was not the major cause of the extensive pathology and ongoing inflammation observed in $\mathrm{CD}^{-1-} 3^{-1}$ mice with colitis. We propose therefore that lack of CD73 expression on the colonic epithelium itself plays a critical role in IBD in $\mathrm{CD} 73^{-/-}$mice.

$\mathrm{CD}^{+} 3^{-/}$mice also exhibited a higher frequency of CD $11 \mathrm{c}^{+}$DCs infiltration in the colon. Mucosal DCs located in the epithelial dome of the colonic patches or in colonic lymphoid follicles are known to be involved in endocytosis and presentation of luminal antigens $[42,43]$. The colonic epithelium is critical for maintenance of immune homeostasis in the colonic environment [44-46]. It does this in part by keeping mucosal DCs in a quiescent state [44-46]. The location and increase in these DCs suggest that they may be involved in presentation of luminal antigens and propagation of colonic inflammatory immune responses, driven by the activated inflammatory colonic epithelial cells in $\mathrm{CD}_{73^{-/-}}$mice. It is also possible that $\mathrm{CD} 73$ expression on the intestinal vasculature could play a role in regulating intestinal inflammation. Future studies would be able to address these questions.

The intestinal epithelium plays a critical role in maintaining the homeostasis of the intestinal environment [8]. It does this in multiple ways including regulation of TLRs, $\mathrm{NF}-\kappa \mathrm{B}$, innate and adaptive immune responses, as well as by providing a physical barrier comprised of junction molecules that separate the luminal contents from the underlying lamina propria [8]. Whole colons from DSS-treated CD73-/mice produce high levels of TNF- $\alpha$ and IL- $1 \beta$ over the course of DSS treatment. IL- $1 \beta$ was detectable in colonic epithelial preparation in non-DSS-treated $\mathrm{CD}_{73^{-/}}$mice and remains elevated even after DSS treatment is aborted. Both IL- $1 \beta$ and TNF- $\alpha$ are well-known contributors to the pathogenesis of colitis in mice and humans [32]. Consistent with this ongoing inflammatory program, constitutively high levels of the transcription factor NF- $\kappa \mathrm{B}$, which is a critical mediator in inflammatory and remodeling responses, are also observed. Both IL- $1 \beta$ and TNF- $\alpha$ are potent activators of NF- $\kappa$ B. NF$\kappa \mathrm{B}$ is a key player in the cycle of inflammation in $\mathrm{CD}$ and is found constitutively active in colonic epithelial cells in IBD [47]. Adenosine is a negative regulator of NF- $\kappa \mathrm{B}$ in human intestinal epithelial cells $[36,47]$. The increase in IL-1 $\beta$ levels during and after DSS treatment correlates with active NF- $\kappa$ B protein and ongoing inflammation and pathology in colons of $\mathrm{CD}^{-1-}$ mice. Although IL-1 $\beta$ is observed in non-DSS-treated $\mathrm{CD}^{-1} 3^{-/}$mice, albeit lower than is seen in DSS treatment, these mice do not display any signs of colon pathology. Therefore, we hypothesize that an inflammatory trigger (DSS) in the absence of extracellular adenosine in $\mathrm{CD}^{-1-}$ mice results in elevated IL- $1 \beta$ that is unresolved even after the trigger is removed. This potentially can contribute to the severe and unresolved inflammation in $\mathrm{CD} 73^{-/-}$but not in WT mice.

Intestinal epithelial cells express a spectrum of Tolllike receptors (TLRs), recognize and respond to microbial products (MAMP/PAMPS), and can trigger inflammatory responses by mucosal immune cells. Studies have shown that exposure of the apical side of a polarized epithelial barrier to the TLR9 ligand, CpG DNA, results in a decreased ability to produce inflammatory cytokines, such as IL-6 and IL-8 [41, 48]. However, basolateral stimulation of the epithelial barrier with the same agent resulted in a potent proinflammatory response [48]. Colons of $\mathrm{CD}^{-1-}$ mice with colitis exhibited increased TLR9 expression that is consistent with the heightened and unresolved inflammation in $\mathrm{CD} 73^{-/-}$mice but not in WT mice with colitis. Increased TLR9 expression, together with the increase in proinflammatory cytokines such as TNF$\alpha$ and constitutive NF- $\kappa$ B activity, is indicative of an activated intestinal epithelium. We hypothesize that the ongoing inflammation in $\mathrm{CD} 73^{-/-}$mice could potentially be due to a breakdown of the intestinal epithelial barrier that leads to leakage of luminal antigens (PAMPS/MAMPS) into the lamina propria and activation of innate receptors like TLR9. Altered TLR expression is commonly associated with chronic inflammatory diseases including IBD. An inflammatory reaction is only required when an antigen is able to bypass 
the protective epithelial barrier. Consistent with the idea of a severely compromised barrier, $\mathrm{CD} 73^{-/-}$mice express significantly lower levels of JAM-A protein and decreased levels of JAM-4 and $\alpha$-catenin transcripts. The increased gastrointestinal permeability in $\mathrm{CD}^{-/-}$mice would allow easy passage of commensal bacteria or their ligands across the epithelial barrier, resulting in stimulation of basolateral TLRs and production of proinflammatory cytokines. These findings strongly indicate that the lack of CD73 expression on colonic epithelial cells plays a critical role in the ongoing inflammation in $\mathrm{CD}_{73^{-/-}}$mice. This leads us to conclude that extracellular adenosine function in the colon is critical for regulation of colonic immune responses and for the resolution of the inflammatory program and establishment of intestinal homeostasis.

In summary, our data show that the lack of CD73 expression on effector immune cells and on colonic epithelium causes severe IBD in $\mathrm{CD} 73^{-/-}$mice. While effector immune cells in $\mathrm{CD}_{73^{-/-}}$mice contribute to IBD pathogenesis, it appears that the greater degree of inflammation and colonic tissue damage is caused by a lack of CD73 expression on the colonic epithelium. This results in breakdown of the epithelial barrier, possibly leading to infiltration of luminal antigens and subsequent presentation of microbial products and activation of immune responses by innate and adaptive immune cells. This perpetuates a vicious cycle of unresolved inflammation due to the lack of CD73-generated adenosine. We conclude therefore that CD73 expression on colonic immune cells is important for immune regulation whereas CD73 expression on colonic tissue is critical for regulating the magnitude and the resolution of the mucosal immune response. These studies provide deeper insights into adenosine's role in mucosal immunity and demonstrate the potential for future development of adenosinergic therapy in treatment of colitis.

\section{Authors' Contribution}

A. T. Waickman and D. A. Mohamed contributed equally to this work.

\section{Acknowledgments}

The authors thank Dr. Gerald Duhamel for help with analysis of colon pathology and Michael Kaplan for reading the paper. This work was supported by Grants from the National Institutes of Health A1072434-A2 and R01NS063011 (to M. S. Bynoe).

\section{References}

[1] P. L. Lakatos and L. S. Kiss, "Is the disease course predictable in inflammatory bowel diseases?" World Journal of Gastroenterology, vol. 16, no. 21, pp. 2591-2599, 2010.

[2] Y. R. Mahida, "Microbial-gut interactions in health and disease. Epithelial cell responses," Best Practice \& Research Clinical Gastroenterology, vol. 18, no. 2, pp. 241-253, 2004.

[3] Y. R. Mahida and V. E. Rolfe, "Host-bacterial interactions in inflammatory bowel disease," Clinical Science, vol. 107, no. 4, pp. 331-341, 2004.
[4] P. Munkholm, E. Langholz, D. Hollander et al., "Intestinal permeability in patients with Crohn's disease and ulcerative colitis and their first degree relatives," Gut, vol. 35, no. 1, pp. 68-72, 1994.

[5] B. Sonier, C. Patrick, P. Ajjikuttira, and F. W. Scott, "Intestinal immune regulation as a potential diet-modifiable feature of gut inflammation and autoimmunity," International Reviews of Immunology, vol. 28, no. 6, pp. 414-445, 2009.

[6] B. Newman, M. S. Silverberg, X. Gu et al., "CARD15 and HLA DRB1 alleles influence susceptibility and disease localization in Crohn's disease," American Journal of Gastroenterology, vol. 99, no. 2, pp. 306-315, 2004.

[7] S. R. Brant and Y. Y. Shugart, "Inflammatory bowel disease gene hunting by linkage analysis: rationale, methodology, and present status of the field," Inflammatory Bowel Diseases, vol. 10, no. 3, pp. 300-311, 2004.

[8] J. R. Turner, "Intestinal mucosal barrier function in health and disease," Nature Reviews Immunology, vol. 9, no. 11, pp. 799$809,2009$.

[9] I. Bjarnason, A. MacPherson, and D. Hollander, "Intestinal permeability: an overview," Gastroenterology, vol. 108, no. 5, pp. 1566-1581, 1995.

[10] D. J. Friedman, B. M. Künzli, Y. I. A-Rahim et al., "CD39 deletion exacerbates experimental murine colitis and human polymorphisms increase susceptibility to inflammatory bowel disease," Proceedings of the National Academy of Sciences of the United States of America, vol. 106, no. 39, pp. 16788-16793, 2009.

[11] N. A. Louis, A. M. Robinson, C. F. MacManus, J. Karhausen, M. Scully, and S. P. Colgan, "Control of IFN- $\alpha$ A by CD73: implications for mucosal inflammation," Journal of Immunology, vol. 180, no. 6, pp. 4246-4255, 2008.

[12] Z. Selmeczy, B. Csóka, P. Pacher, E. S. Vizi, and G. Haskó, "The adenosine A2A receptor agonist CGS 21680 fails to ameliorate the course of dextran sulphate-induced colitis in mice," Inflammation Research, vol. 56, no. 5, pp. 204-209, 2007.

[13] C. M. Cruz, A. Rinna, H. J. Forman, A. L. M. Ventura, P. M. Persechini, and D. M. Ojcius, "ATP activates a reactive oxygen species-dependent oxidative stress response and secretion of proinflammatory cytokines in macrophages," The Journal of Biological Chemistry, vol. 282, no. 5, pp. 2871-2879, 2007.

[14] G. Haskó, J. Linden, B. Cronstein, and P. Pacher, "Adenosine receptors: therapeutic aspects for inflammatory and immune diseases," Nature Reviews Drug Discovery, vol. 7, no. 9, pp. 759-770, 2008.

[15] L. Airas, J. Niemelä, M. Salmi, T. Puurunen, D. J. Smith, and S. Jalkanen, "Differential regulation and function of CD73, a glycosyl- phosphatidylinositol-linked 70-kD adhesion molecule, on lymphocytes and endothelial cells," Journal of Cell Biology, vol. 136, no. 2, pp. 421-431, 1997.

[16] L. Antonioli, M. Fornai, R. Colucci et al., "Pharmacological modulation of adenosine system: novel options for treatment of inflammatory bowel diseases," Inflammatory Bowel Diseases, vol. 14, no. 4, pp. 566-574, 2008.

[17] S. Gessi, S. Merighi, K. Varani et al., "Adenosine receptors in colon carcinoma tissues and colon tumoral cell lines: focus on the A3 adenosine subtype," Journal of Cellular Physiology, vol. 211, no. 3, pp. 826-836, 2007.

[18] M. L. Hart, M. Henn, D. Köhler et al., "Role of extracellular nucleotide phosphohydrolysis in intestinal ischemia-reperfusion injury," The FASEB Journal, vol. 22, no. 8, pp. 27842797, 2008. 
[19] K. Synnestvedt, G. T. Furuta, K. M. Comerford et al., "Ecto-5' nucleotidase (CD73) regulation by hypoxia-inducible factor-1 mediates permeability changes in intestinal epithelia," Journal of Clinical Investigation, vol. 110, no. 7, pp. 993-1002, 2002.

[20] S. Deaglio, K. M. Dwyer, W. Gao et al., "Adenosine generation catalyzed by CD39 and CD73 expressed on regulatory $\mathrm{T}$ cells mediates immune suppression," Journal of Experimental Medicine, vol. 204, no. 6, pp. 1257-1265, 2007.

[21] M. Odashima, G. Bamias, J. Rivera-Nieves et al., "Activation of $\mathrm{A} 2 \mathrm{~A}$ adenosine receptor attenuates intestinal inflammation in animal models of inflammatory bowel disease," Gastroenterology, vol. 129, no. 1, pp. 26-33, 2005.

[22] B. Siegmund, F. Rieder, S. Albrich et al., "Adenosine kinase inhibitor GP515 improves experimental colitis in mice," Journal of Pharmacology and Experimental Therapeutics, vol. 296, no. 1, pp. 99-105, 2001.

[23] L. F. Thompson, H. K. Eltzschig, J. C. Ibla et al., "Crucial role for ecto- $5^{\prime}$-nucleotidase (CD73) in vascular leakage during hypoxia," Journal of Experimental Medicine, vol. 200, no. 11, pp. 1395-1405, 2004.

[24] C. G. Whittem, A. D. Williams, and C. S. Williams, "Murine Colitis modeling using Dextran Sulfate Sodium (DSS)," JoVE: Journal of Visualized Experiments, no. 35, article e1652, 2010.

[25] Y. Obata, D. Takahashi, M. Ebisawa et al., "Epithelial cellintrinsic Notch signaling plays an essential role in the maintenance of gut immune homeostasis," Journal of Immunology, vol. 188, no. 5, pp. 2427-2436, 2012.

[26] J. H. Mills, L. Alabanza, B. B. Weksler, P. O. Couraud, I. A. Romero, and M. S. Bynoe, "Human brain endothelial cells are responsive to adenosine receptor activation," Purinergic Signalling, vol. 7, no. 2, pp. 265-273, 2011.

[27] F. Powrie, "T cells in inflammatory bowel disease: protective and pathogenic roles," Immunity, vol. 3, no. 2, pp. 171-174, 1995.

[28] F. Powrie, M. W. Leach, S. Mauze, L. B. Caddle, and R. L. Coffman, "Phenotypically distinct subsets of CD4+ T cells induce or protect from chronic intestinal inflammation in C. B-17 scid mice," International Immunology, vol. 5, no. 11, pp. 1461-1471, 1993.

[29] J. H. Mills, L. F. Thompson, C. Mueller et al., "CD73 is required for efficient entry of lymphocytes into the central nervous system during experimental autoimmune encephalomyelitis," Proceedings of the National Academy of Sciences of the United States of America, vol. 105, no. 27, pp. 9325-9330, 2008.

[30] S. P. Colgan, H. K. Eltzschig, T. Eckle, and L. F. Thompson, "Physiological roles for ecto-5'-nucleotidase (CD73)," Purinergic Signalling, vol. 2, no. 2, pp. 351-360, 2006.

[31] A. I. Ivanov, A. Nusrat, and C. A. Parkos, "The epithelium in inflammatory bowel disease: potential role of endocytosis of junctional proteins in barrier disruption," Novartis Foundation Symposium, vol. 263, pp. 115-124, 2004.

[32] G. Rogler and T. Andus, "Cytokines in inflammatory bowel disease," World Journal of Surgery, vol. 22, no. 4, pp. 382-389, 1998.

[33] K. Kimura, S. Teranishi, and T. Nishida, "Interleukin-1 $\beta$ induced disruption of barrier function in cultured human corneal epithelial cells," Investigative Ophthalmology and Visual Science, vol. 50, no. 2, pp. 597-603, 2009.

[34] A. A. Beg, T. S. Finco, P. V. Nantermet, and A. S. Baldwin Jr., "Tumor necrosis factor and interleukin-1 lead to phosphorylation and loss of $\mathrm{I} \kappa \mathrm{B} \alpha$ : a mechanism for NF- $\kappa \mathrm{B}$ activation," Molecular and Cellular Biology, vol. 13, no. 6, pp. 3301-3310, 1993.
[35] A. Kaser, S. Zeissig, and R. S. Blumberg, "Inflammatory bowel disease," Annual Review of Immunology, vol. 28, pp. 573-621, 2010.

[36] S. Morello, K. Ito, S. Yamamura et al., "IL-1 $\beta$ and TNF$\alpha$ regulation of the adenosine receptor (A 2A) expression: differential requirement for NF- $\kappa \mathrm{B}$ binding to the proximal promoter," Journal of Immunology, vol. 177, no. 10, pp. 71737183, 2006.

[37] D. R. Clayburgh, L. Shen, and J. R. Turner, "A porous defense: the leaky epithelial barrier in intestinal disease," Laboratory Investigation, vol. 84, no. 3, pp. 282-291, 2004.

[38] M. A. McGuckin, R. Eri, L. A. Simms, T. H. J. Florin, and G. Radford-Smith, "Intestinal barrier dysfunction in inflammatory bowel diseases," Inflammatory Bowel Diseases, vol. 15, no. 1, pp. 100-113, 2009.

[39] M. G. Laukoetter, P. Nava, W. Y. Lee et al., "JAM-A regulates permeability and inflammation in the intestine in vivo," Journal of Experimental Medicine, vol. 204, no. 13, pp. 30673076, 2007.

[40] S. Nell, S. Suerbaum, and C. Josenhans, "The impact of the microbiota on the pathogenesis of IBD: lessons from mouse infection models," Nature Reviews Microbiology, vol. 8, no. 8, pp. 564-577, 2010.

[41] M. T. Abreu, "Toll-like receptor signalling in the intestinal epithelium: how bacterial recognition shapes intestinal function," Nature Reviews Immunology, vol. 10, no. 2, pp. 131-143, 2010.

[42] J. H. Niess, "Role of gut-resident dendritic cells in inflammatory bowel disease," Expert Review of Clinical Immunology, vol. 5, no. 4, pp. 451-461, 2009.

[43] P. N. Fries and P. J. Griebel, "Mucosal dendritic cell diversity in the gastrointestinal tract," Cell and Tissue Research, vol. 343, no. 1, pp. 33-41, 2011.

[44] M. Mavris and P. Sansonetti, "Microbial-gut interactions in health and disease. Epithelial cell responses," Best Practice \& Research Clinical Gastroenterology, vol. 18, no. 2, pp. 373-386, 2004.

[45] M. Rescigno, "The intestinal epithelial barrier in the control of homeostasis and immunity," Trends in Immunology, vol. 32, no. 6, pp. 256-264, 2011.

[46] J. M. Wells, O. Rossia, M. Meijerink, and P. Van Baarlen, "Epithelial crosstalk at the microbiota-mucosal interface," Proceedings of the National Academy of Sciences of the United States of America, vol. 108, no. 1, pp. 4607-4614, 2011.

[47] H. B. Jijon, J. Walker, F. Hoentjen et al., "Adenosine is a negative regulator of NF- $\kappa \mathrm{B}$ and MAPK signaling in human intestinal epithelial cells," Cellular Immunology, vol. 237, no. 2, pp. 86-95, 2005.

[48] J. Lee, J. H. Mo, K. Katakura et al., "Maintenance of colonic homeostasis by distinctive apical TLR9 signalling in intestinal epithelial cells," Nature Cell Biology, vol. 8, no. 12, pp. 13271336, 2006. 

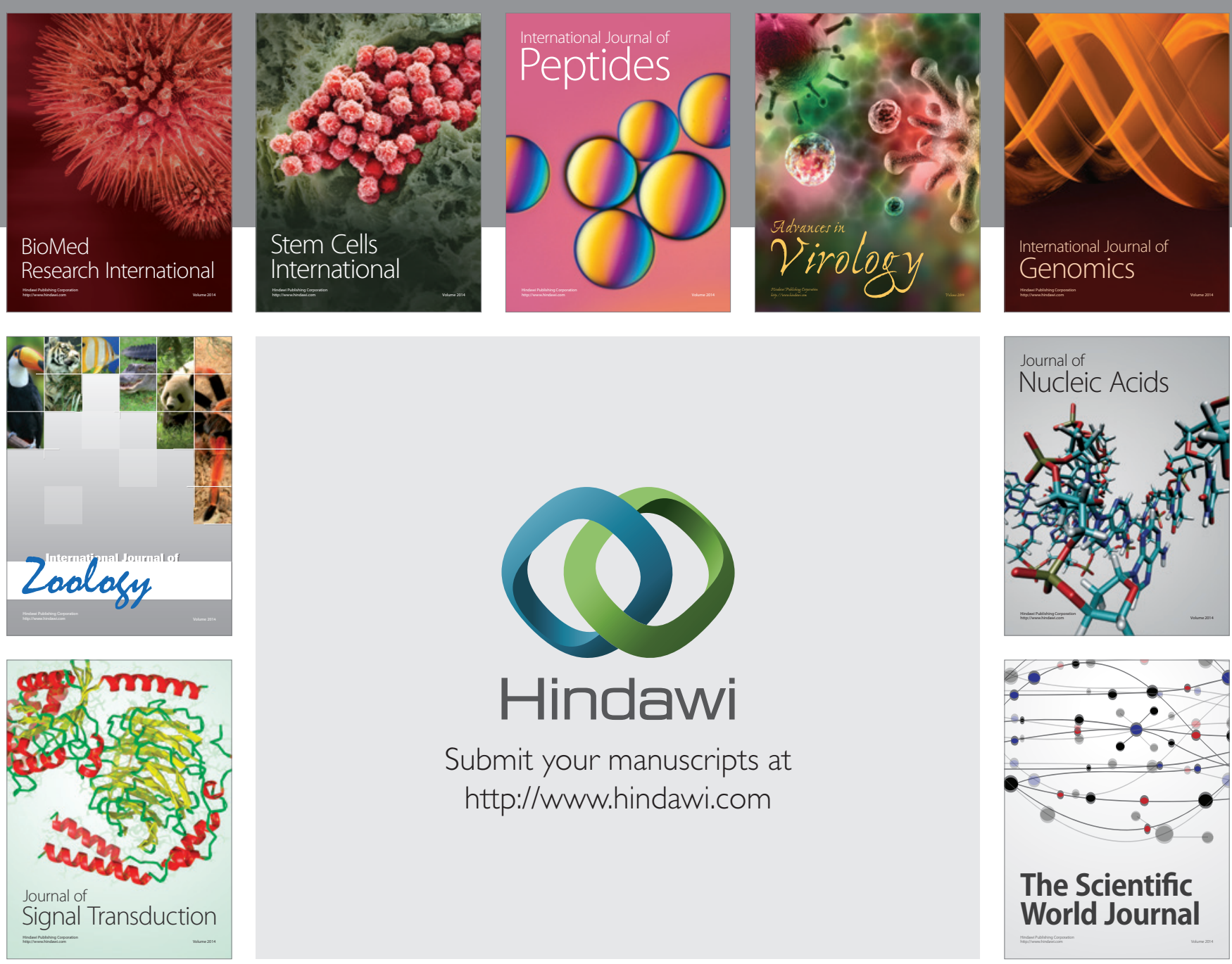

Submit your manuscripts at

http://www.hindawi.com
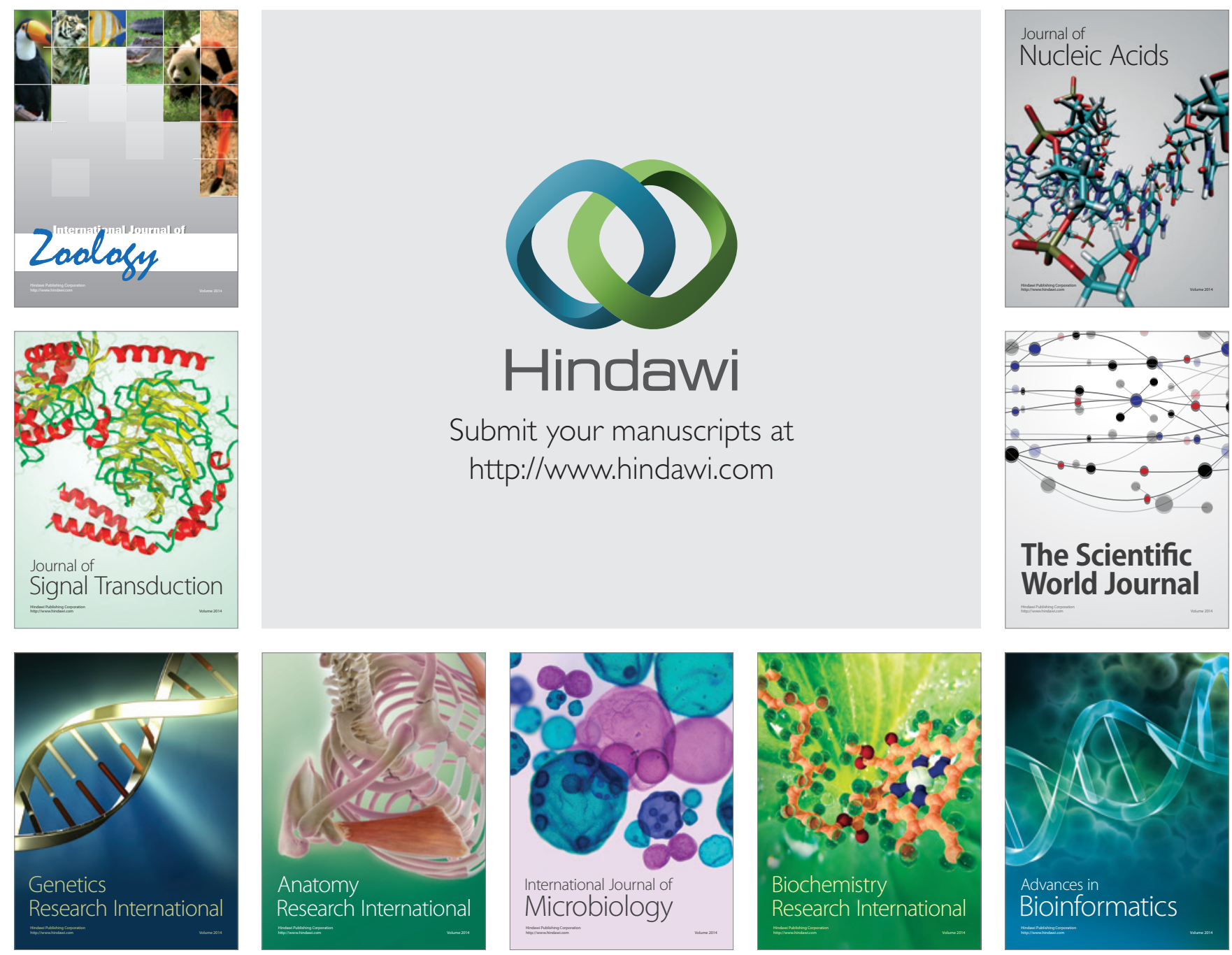

The Scientific World Journal
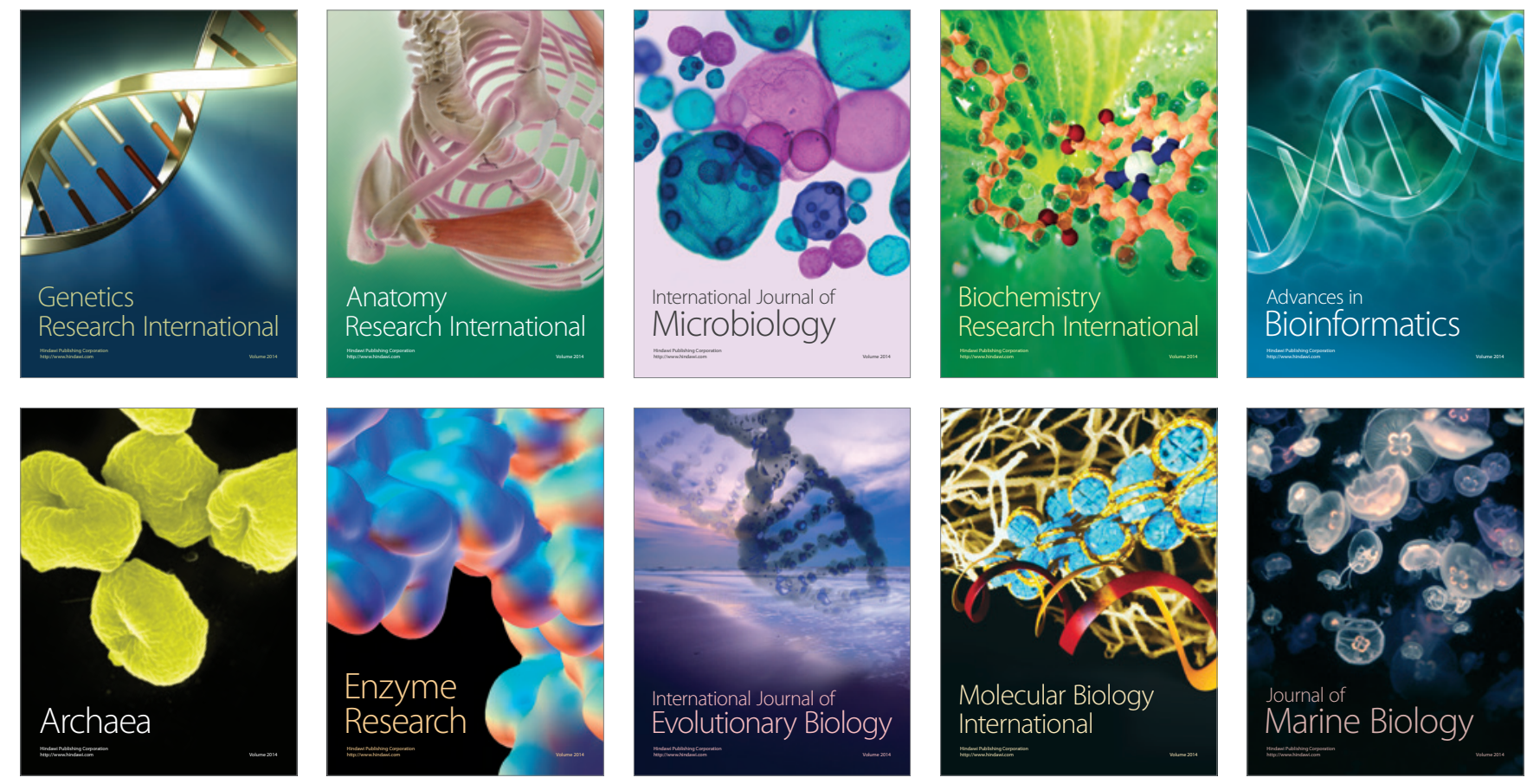